\title{
Pemodelan Revalidasi Sertifikat Keterampilan Kepelautan Jarak Jauh: Validasi Dan Penilaian
}

\author{
Vidya Selasdini ${ }^{1}$, Antoni Arif Priadi ${ }^{2}$, Rr. Retno S. Wulandari ${ }^{3}$, Nurul Iman ${ }^{4}$ \\ ${ }^{1}$ Prodi Ketatalaksanaan Angkutan Laut dan Kepelabuhanan \\ ${ }^{2,3,4}$ Prodi Nautika \\ Sekolah Tinggi Ilmu Pelayaran, Jakarta \\ Jl. Marunda Makmur No. 1 Cilincing, Jakarta Utara. Jakarta 14150
}

\begin{abstract}
Abstrak
Ketika seorang pelaut ingin merevalidasi sertifikatnya, maka pelaut tersebut diharuskan hadir dan mengikuti kembali assessment sebagai tahapan akhir dari proses kegiatan revalidasi. Banyak pelaut yang mungkin keberatan dengan kondisi ini karena waktu yang mereka miliki sebenarnya tidaklah cukup banyak untuk melakukan itu. Masalah yang dikaji dalam penelitian ini yaitu bagaimana validasi dan penilaian/asesmen dapat dilakukan terhadap peserta revalidasi sertifikat keterampilan terbitan STIP secara jarak jauh. Kemudian tujuan penelitian ini adalah membuat model validasi dan penilaian/asesmen dapat dilakukan terhadap peserta revalidasi sertifikat keterampilan secara jarak jauh sehingga dapat mempercepat pelayanan sertifikasi kepelautan. Jenis Penelitian yang digunakan adalah kuantitatif. Dari hasi penelitian diperoleh kesimpulan bahwa Pelaksanaan revalidasi sertifikat BST secara online di STIP dapat dilaksanakan dengan tetap memperhatikan ketentuan persyaratan mulai dari proses pendaftaran, evaluasi sampai dengan penerbitan sertifikat revalidasi. Legalitas sertifikat revalidasi sertifikat yang dilakukan dengan jarak jauh adalah sama dan legal seperti sertifikat revalidasi yang dilakukan secara reguler. Seluruh rangkaian proses dilakukan sesuai SOP yang berlaku dan tidak memberikan celah untuk dilakukannya tindakan penipuan.
\end{abstract}

Copyright $(2020$, Prosiding Seminar Penelitian Pelayaran dan Riset Terapan Kata Kunci: pemodelan, revalidasi, sertifikat kepelautan, jarak jauh

\section{PENDAHULAN}

Negara Indonesia adalah salah satu negara terbesar di dunia yang memiliki populasi pelaut terbesar setelah Filipina, Cina, Rusia dan Ukraina. Populasi pelaut di seluruh dunia yang melayani kapal-kapal niaga dengan rute internasional diperkirakan sebanyak 1.647 .500 pelaut, di mana 774.000 diantaranya adalah perwira dan 873.500 adalah ratings. Filipina adalah pemasok pelaut untuk posisi rating dengan peringkat terbesar, diikuti oleh Cina, Indonesia, Federasi Rusia dan Ukraina. Sementara China adalah pemasok perwira kapal terbesar, diikuti oleh Filipina, India, Indonesia dan Federasi Rusia. (international chamber of shipping-2019)

Permintaan global untuk pelaut diperkirakan mencapai 1.545.000, dengan posisi dibutuhkan sekitar 790.500 orang Perwira dan 754.500 untuk Rating. Ini menunjukkan bahwa permintaan untuk jumlah perwira diatas kapal telah meningkat sekitar $24,1 \%$, sedangkan permintaan untuk rating diatas kapal telah meningkat sekitar 1,0\%.

Pada tahun 2005, BIMCO / ISF melaporkan bahwa ada defisit 10.000 perwira maritim untuk kapal-kapal global (BIMCO / ISF, 2005). Pada tahun 2010, jumlahnya meningkat menjadi 13.000 (BIMCO / ISF, 2010). Drewry (2015) melaporkan bahwa ada defisit sebesar 19.000 untuk jabatan Perwira diatas kapal. Setahun kemudian, BIMCO / ISF (2015) menunjukkan bahwa ada kekurangan sebanyak 16.500 perwira kapal secara global, Jumlah ini diperkirakan akan meningkat menjadi 147.500 pada tahun 2025 .

Indonesia sendiri saat ini memiliki pelaut yang tersebar baik di kapal-kapal berbendera asing, maupun kapala-kapal berbendera Indonesia. Pengaruh asas cabotage memberikan keuntungan tersendiri bagi komunitas pelaut di Indonesia, sebab dengan lahirnya asas tersebut secara tidak langsung memberikan peluang bagi warga negara Indonesia untuk bekerja diatas kapal. Tingginya minat masyarakat Indonesia untuk bekerja di dunia maritime didorong pula dengan adanya Instruksi Presiden NOmor 9 Tahun 2016 tentang revitalisasi Sekolah Menengah Kejuaruan (SMK) dalam rangka peningkaran kualitas dan daya saing Sumber daya Manusia Indonesia .

Sebagian besar dari para pelaut yag telah mengambil diklat tersebut selanjutnya bekerja di 
atas kapal-kapal niaga, hanya beberapa saja yang bekerja di kapal negara ataupun kapal ikan. Presiden Jokowi melalui visinya membangun tol maritim secara tidak langsung memberikan amanah bagi para pelaksana diklat kepelautan untuk memberikan pelayan terbaik dan ketersediaan bagi pelaut-pelaut Indonesia.

Berbicara mengenai pelayanan kepada pelaut, merupakan sesuatu hal yang agak unik, sebab kondisi dan lingkungan pekerjaan pelaut yang memang tidak lazim seperti pekerjaan pada umumnya. Misalnya saja kontrak kerja yang berkisar tiga sampai dua belas bulan diatas kapal. Selama masa kontrak tersebut maka para pelaut tidak diperkenankan pulang ke rumah. Lokasi pekerjaan yang berada di tengah laut dengan cuaca ekstrim yang selalu menemani Para pelaut bekerja, menjadi pertimbangan tersendiri bagi Perusahaan dalam memberikan kompesasi / gaji kepada mereka.

Ritme pekerjaan seorang pelaut pun harus menyesuaikan dengan alur bisnis yang dilakukan oleh Perusahaan Pelayaran dalam dunia maritim. Ada kalanya sebuah kapal hanya melakukan sandar selama dua jam saja di Pelabuhan untuk melakukan bongkar muat dan selanjutnya kembali lagi berlayar. Atau kapal harus berlayar dari suatu negara ke negara tertentu dengan melintasi benua yang berbeda.

Kondisi inilah yang menyebabkan betapa berartinya sebuah waktu bagi para pelaut terutama ketika mereka memiliki waktu di darat. STIP sebagai Penyelenggara diklat kepelautan terbesar di Indonesia selalu berkomitmen untuk memberikan Pelayanan yang cepat dan tepat. Ramsoek (2010) mengemukakan bahwa kualitas pelayanan merupakan kemampuan dari suatu organisasi untuk memenuhi atau melebihi harapan konsumen.

Definisi lain mengenai kualitas pelayanan diberikan oleh Lewis dan booms (1983), dalam Tjiptono (2005:121) yang mendefinisikan kualitas pelayanan sebagai ukuran seberapa bagus tingkat layanan yang diberikan mampu sesuai dengan ekspektasi pelanggan. Mengacu pada definisi tersebut, Tjiptono menambahkan pula bahwa kualitas pelayanan dapat diwujudkan melalui pemenuhan kebutuhan dan keinginan pelanggan serta ketepatan penyampaianya untuk mengimbangi harapan pelanggan. Dengan demikian kualitas pelayanan dipengaruhi oleh dua factor yaitu customer expectation (harapan pelanggan) dan customer perceived (yang dirasakan pelanggan) atas suatu pelayanan.

Salah satu layanan yang diberikan oleh STIP yaitu revalidasi sertifikat kepelautan untuk Basic Safety Training (BST). Sesuai dengan STCW
Amandemen 2010, Tabel B I/2 List of Certificates of Documentary Evidence Required Under the STCW Convention, maka ada beberapa sertifikat yag perlu dilakukan revalidasi, diantaranya yaitu: Tabel 1. Daftar Sertifikat yang perlu di Revalidasi

\begin{tabular}{|c|c|c|c|c|}
\hline No & Sertifikat & $\begin{array}{c}\text { Endor- } \\
\text { semen } \\
\mathrm{t}\end{array}$ & $\begin{array}{l}\text { Revali- } \\
\text { dasi }\end{array}$ & Aturan \\
\hline 1 & $\begin{array}{l}\text { GMDSS Radio } \\
\text { Operator }\end{array}$ & $\mathrm{Ya}$ & Ya & $\begin{array}{l}\text { II/1, } \\
\text { II/2,II/3, } \\
\text { III/1, } \\
\text { III/2,III/ } \\
3, \text { III/6,I } \\
\text { V/2,VII/ } \\
2 \\
\end{array}$ \\
\hline 2 & $\begin{array}{l}\text { Ratings as } \\
\text { Navigational or } \\
\text { Engine room } \\
\text { watch }\end{array}$ & Tidak & Tidak & $\begin{array}{l}\mathrm{II} / 4, \\
\mathrm{III} / 4, \\
\mathrm{VII} / 2\end{array}$ \\
\hline 3 & $\begin{array}{l}\text { Ratings as Able } \\
\text { seafarer deck, } \\
\text { able seafarer } \\
\text { engine atau } \\
\text { electro - } \\
\text { technical rating }\end{array}$ & Tidak & Tidak & $\begin{array}{l}\mathrm{II} / 5, \\
\mathrm{III} / 5, \\
\mathrm{III} / 7 \\
\mathrm{VII} / 2\end{array}$ \\
\hline 4 & $\begin{array}{l}\text { CoP atau } \\
\text { endorsement } \\
\text { CoC untuk } \\
\text { Masters and } \\
\text { Officers on } \\
\text { Oil,Chemical or } \\
\text { liquefied gas } \\
\text { tankers }\end{array}$ & $\mathrm{Ya}$ & $\mathrm{Ya}$ & $\begin{array}{l}\mathrm{V} / 1-1, \\
\mathrm{~V} / 1-2\end{array}$ \\
\hline 5 & $\begin{array}{l}\text { CoP untuk } \\
\text { Ratings on } \\
\text { Oil,checmical or } \\
\text { liquefied gas } \\
\text { tankers }\end{array}$ & Tidak & Tidak & $\begin{array}{l}V / 1-1, \\
V / 1-2\end{array}$ \\
\hline 6 & $\begin{array}{l}\mathrm{CoP}-\text { basic } \\
\text { Training }\end{array}$ & Tidak & Ya & $\mathrm{V} / 1-1$ \\
\hline 7 & $\begin{array}{l}\text { CoP }- \text { SCRB, } \\
\text { dan FRB }\end{array}$ & Tidak & Ya & $\mathrm{V} / 1-2$ \\
\hline 8 & CoP-AFF & Tidak & $\mathrm{Ya}$ & $\mathrm{VI} / 3$ \\
\hline 9 & $\begin{array}{l}\text { CoP - MFA dan } \\
\text { MC }\end{array}$ & Tidak & Tidak & $\mathrm{VI} / 4$ \\
\hline 10 & $\mathrm{CoP}$ - SSO & Tidak & Tidak & $\mathrm{VI} / 5$ \\
\hline 11 & $\begin{array}{l}\text { CoP - SAT atau } \\
\text { SDSD }\end{array}$ & Tidak & Tidak & $\mathrm{VI} / 6$ \\
\hline 12 & $\begin{array}{l}\text { CoP - Ships } \\
\text { Operating in } \\
\text { Polar Waters } \\
\end{array}$ & Tidak & Ya & $\mathrm{V} / 4$ \\
\hline 13 & $\begin{array}{l}\text { CoP - Ships } \\
\text { Subjects to the } \\
\text { IGF Code }\end{array}$ & Tidak & $\mathrm{Ya}$ & $\mathrm{V} / 3$ \\
\hline 14 & $\begin{array}{l}\text { Documentary } \\
\text { Evidence - } \\
\text { Training } \\
\text { personnel } \\
\text { serving on } \\
\text { Passanger ships }\end{array}$ & Tidak & Tidak & $\mathrm{V} / 2$ \\
\hline
\end{tabular}


Pemerintah Indonesia pun sudah menurunkan aturan ini melalui surat edaran dari Direktur Perkapalan dan Kepelautan Direktorat Jenderal Perhubungan Laut (DJPL) NO: UM .003/2412/DK-18 tentang Pelaksanaan Revalidasi Program Diklat Kepelautan. Hal ini menjadi kewajiban bagi seluruh pelaut di Indonesia untuk selalau merevalidasi atau merefresh dokumen kepelautannya (Certificate of Proficiency). Pengurusan dokumen kepelautan tersebut hanya dapat dilaksanakan oleh para Unit Pelaksana Teknis/Penyelenggara Diklat yang telah mendapatkan izin atau approval dari Direktorat Jenderal Perkapalan dan Kepelautan,Kementerian Perhubungan. Dan STIP adalah salah satunya. UPT lain selain STIP tersebar di seluruh Indonesia, mulai dari Aceh sampai dengna Sorong.

Berdasarkan kondisi pelaut dan data yang telah disebutkan diatas, maka sudah sepatutnya para pelaut mendapatkan pelayanan yang cepat dan tepat. Banyak dari para pelaut yang datang ke STIP berasal dari kota-kota di luar Jakarta seperti misalnya dari daerah Pulau Sumatera, Kalimantan, Sulawesi, bahkan sampai ke Papua. Lokasi tempat diklat yang jauh dari tempat tinggal menjadi kendala dan masalah bagi mereka. Banyaknya uang yang harus dikeluarkan untuk membayar ongkos transportasi, tempat tinggal dan biaya hidup selama di Jakarta menjadi beban yang tidak bisa dihindarkan.

Ketika seorang pelaut ingin merevalidasi sertfifikatnya, maka pelaut tersebut diharuskan hadir dan mengikuti kembali assessment sebagai tahapan akhir dari proses kegiatan revalidasi. Banyak pelaut yang mungkin keberatan dengan kondisi ini karena waktu yang mereka miliki sebenarnya tidaklah cukup banyak untuk melakukan itu. Mereka hanya dapat melakukan revalidasi hanya ketika mereka telah menyelesaikan kontrak di kapal. Ketiak berada di atas kapal, mereka belum bisa melakukan revalidasi. Melihat kondisi inilah maka para penulis teratarik untuk memberikan sebuah solusi kepada para pelaut terutama dalam mengefisiensikan waktu dan biaya.

Solusi yang mungkin dapat ditawarkan yaitu dengan adanya system validasi secara jarak jauh sehingga dapat menghemat waktu dan tentu saja menghemat biaya. Namun cara ini harus melaui suatu uji penelitian terlebih dahulu sebab belum ada aturan yang memperbolehkan bila proses ini dilakukan secara jarak jauh dengan memanfaatkan tehnologi yang ada.

Berdasarkan hal-hal tersebut di atas maka penelitian ini akan dilakukan uji coba terhadap contoh atau pemodelan sertifikat kepelautan jarak jauh yang diberikan oleh STIP.

Beberapa permasalahan yang masih terlihat dalam pelayanan angkutan penumpang di Pontianak adalah sebagai berikut :

1. Kontrak para pelaut yang cenderung lama di atas kapal.

2. Lokasi pekerjaan yang berada di tengah laut dengan cuaca ekstrim.

3. Waktu sandar yang cepat sewaktu di Pelabuhan Muat/bongkar.

4. Pelaut Indonesia tersebar di seluruh nusantara termasuk daerah pelosok yang masih sulit dijangkau.

5. Lokasi beberapa Unit Pelayanan Teknis (UPT) diklat yang umumnya hanya terdapat di kota besar.

6. Panjangnya sistem prosedur penerbitan revalidasi sertifikat.

Dari berbagai permasalahan di atas, maka pembahasan dilakukan dengan membatasi pada beberapa hal sebagaimana berikut ini :

1. Penerbitan revalidasi sertifikat keterampilan BST

2. Penerbitan untuk sertifikat keterampilan BST keluaran STIP.

Kemudian rumusan masalah dalam penelitian ini yaitu Bagaimana validasi dan penilaian/asesmen dapat dilakukan terhadap peserta revalidasi sertifikat keterampilan terbitan STIP secara jarak jauh?

Kemudian tujuan penelitian ini adalah membuat model validasi dan penilaian/asesmen dapat dilakukan terhadap peserta revalidasi sertifikat keterampilan secara jarak jauh sehingga dapat mempercepat pelayanan sertifikasi kepelautan.

Urgensi dilakukannya penelitian ini adalah :

1. Penelitian ini penting dalam rangka meningkatkan kinerja pelayanan STIP terhadap peserta diklat khususnya kepada para pelaut yang tersebar di seluruh Indonesia.

2. Penelitian ini dapat dimanfaatkan sebagai bahan masukan dalam melakukan pendalaman terhadap kepuasan pelanggan dalam menerima pelayanan dari penyelenggara jasa transportasi

\section{METODE}

Penelitian ini sesuai dengan judulnya akan dilakukan di Jakarta dengan target responden meliputi operator dan regulator serta masyarakat pengguna jasa sertifikat keterampilan pelaut yaitu sertifikat Basic Safety Training (BST) . Penelitian ini dilaksanakan selama 3 bulan terhitung mulai Maret 2020.

Metode pengumpulan data dilakukan dengan 2 cara yaitu studi kepustakaan untuk memperoleh 
data sekunder, sedangkan data primer diperoleh dengan meminta opini responden melalui kuesioner. Data sekunder diperoleh dalam bentuk data-data empiris dari pelaku usaha atau instansi terkait serta studi kepustakaan. Data-data empiris yang akan diperoleh antara lain: kunjungan ke penyelenggara diklat, kinerja pelayanan diklat keterampilan, aktivitas revalidasi sertifikat. Data primer adalah data yang bersumber langsung dari informan yang umumnya adalah peserta diklat keterampilan, aparat pemerintah dan pihak terkait lainnya yang bersentuhan dengan kebijakan penerapan sistem revalidasi sertifikat jarak jauh .

Data primer dikemas dalam bentuk kuesioner atau angket yang merupakan teknik pengumpulan data yang dilakukan melalui pemberian pertanyaan-pertanyaan secara tertulis kepada responden untuk dijawab. Pertanyaan kuesioner pada penelitian ini bersifat tertutup. Selain itu, dilakukan pula wawancara dalam rangka mendapatkan masukan pendukung lainnya dari stakeholder terkait.

Populasi penelitian ini adalah seluruh peserta diklat keterampilan pelaut khususnya peserta yang memiliki sertifikat Basic Safety Training (BST) di STIP dan stakeholder atau instansi terkait lainnya. Pengambilan sampel dilakukan secara random sampling mengingat pelaksanaannya relatif lebih mudah dan diharapkan dapat memudahkan pengolahan data dari beberapa sample yang ditentukan. Jumlah sample yang diambil minimal 100 responden yang diwawancarai dan dipandu jika terdapat hal-hal yang belum dipahami dalam pengisian angket kuesioner yang disebarkan di STIP. Pengumpulan data primer ini akan dibantu oleh beberapa rekan operator yang sebelumnya telah dibriefing.

Penelitian ini merupakan jenis penelitian deskriptif kuantitatif dengan rancangan penelitian menggunakan metode survei (non eksperimental). Penelitian/ riset deskriptif merupakan jenis riset yang ingin menjelaskan atau menggambarkan sesuatu yang diuraikan secara kuantitatif. Prosesnya dilakukan melalui analisis data dan informasi eksisting / aktual dan penjaringan opini responden melalui survei terkait dengan upaya untuk mengetahui tingkat pelayanan revalidasi jarak jauh di STIP Jakarta.

Metode analisis data yang digunakan dalam penelitian ini dilakukan secara deskriptif kuantatif untuk memperoleh pemahaman pentingnya pengembangan proses revalidasi secara jarak jauh sesuai dengan tujuan yang ingin dicapai. Langkah-langkah analisis data yang digunakan diuraikan sebagai berikut:

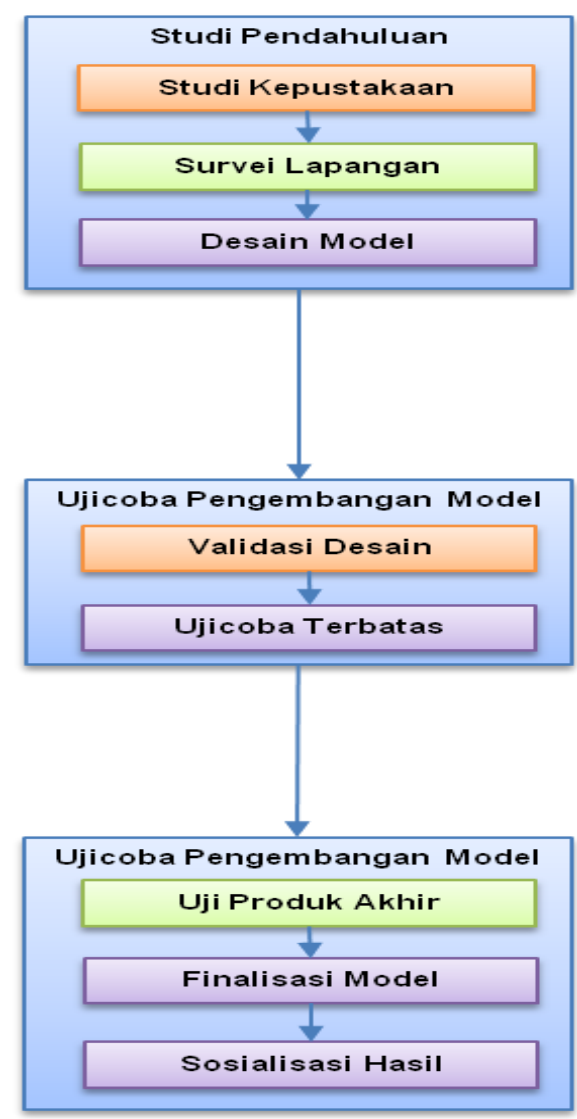

Gambar 1. Langkah Analisis

Penjelasan dari gambar 1 sebagai berikut:

\section{Studi Pustaka}

Studi Pustaka diakukan dengan beberapa model yaitu Distance Assesment, Skype, SOP Revalidasi BST, Kursil BST, SOP Pendaftaran revalidasi BST, SOP Penerbitan sertifikat BST revalidasi

2. Ujicoba Pengembangan Model I

Dilakukan dengan validasi desain danujicoba terabtas dengan cara melakukan Survei pada lokasi tempat tinggal peserta yang mengikuti revalidasi BST (2 minggu pengambilan angket kepada peserta revalidasi)

3. Uji coba Pengembangan Model II

Dilakukan dengan melakukan uji produk akhir, memmfinalisasi model yang sudah dipilih lalu melakukan sosialisaasi hasil kepada pihak terkait.

4. Penarikan Kesimpulan

Data yang terkumpul dan disusun secara rinci untuk selanjutnya dilakukan analisis dan evaluasi sehingga mudah ditarik kesimpulan sebagai jawaban terhadap rumusan masalah yang ditetapkan pada awal penelitian.

Ketika seorang pelaut ingin merevalidasi sertfifikatnya, maka pelaut tersebut diharuskan hadir dan mengikuti kembali assessment sebagai tahapan akhir dari proses kegiatan revalidasi. Banyak pelaut yang mungkin keberatan dengan kondisi ini karena waktu yang mereka miliki 


\section{http://ejournal.stipjakarta.ac.id/index.php/pcsa}

sebenarnya tidaklah cukup banyak untuk melakukan itu. Mereka hanya dapat melakukan revalidasi hanya ketika mereka telah menyelesaikan kontrak di kapal. Melihat kondisi inilah maka para penulis teratarik untuk memberikan sebuah solusi kepada para pelaut terutama dalam mengefisiensikan waktu dan biaya. Solusi yang mungkin dapat ditawarkan yaitu dengan adanya system validasi secara jarak jauh sehingga dapat menghemat waktu dan tentu saja menghemat biaya. Melaui suatu uji penelitian diharapkan nanntinya kemudahan dan sistem uji validasi terhadap penerapan sistem revalidasi jarak jauh dapat digunakan bagi para pelaut-pelaut Indonesia dengan memanfaatkan teknologi yang ada.

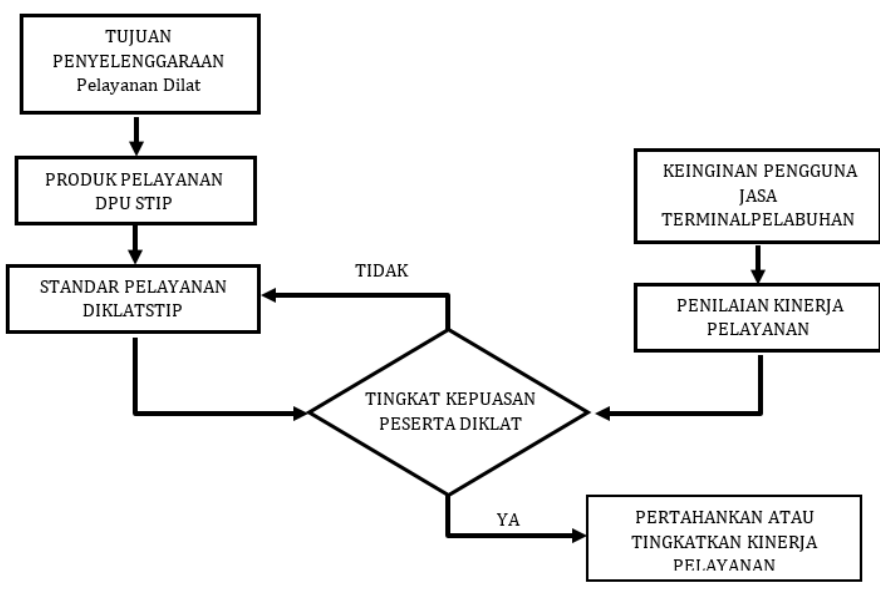

Gambar 2. Kerangka Pemikiran

\section{HASIL DAN PEMBAHASAN}

\subsection{Deskripsi Responden}

Penelitian ini menggunakan data yang diolah dari beberapa jenis questioner. Sebelum melakukan uji ini, kami memberikan questioner yang dibagikan kepada beberapa peserta diklat yang mendaftar di STIP. Berikut dibawah ini adalah hasil questioner dari para responden mengenai kajian tingkat pelayanan revalidasi di STIP.

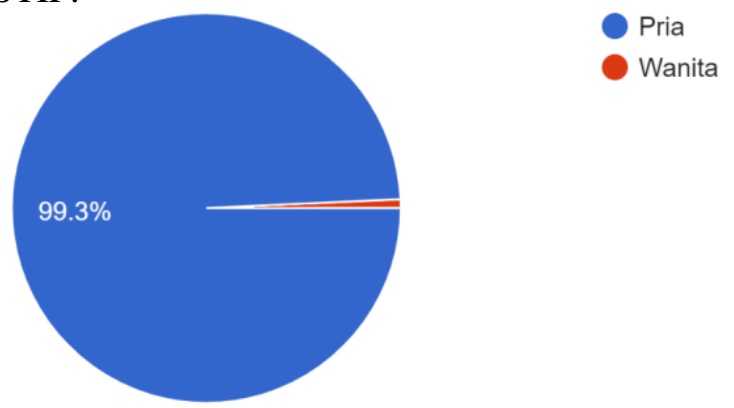

Gambar 3. Diagram Jenis Kelamin Peserta Revalidasi BST

Pada gambar 3 menunjukkan tentang perbandingan jumlah responden berdaasarkan jenis kelamin pria atau wanita. Sebagian besar dari responden adalah pria yaitu sebanyak $99.3 \%$, sedangkan sisanya responden wanita sebanyak $0,7 \%$, hal ini disebabkan oleh karena peserta diklat yang mendaftar menjadi pelaut memang sebagian besar adalah pria.
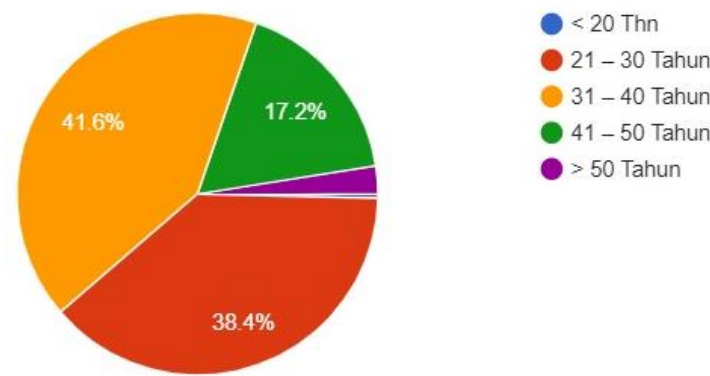

Gambar 4. Diagram Usia Peserta Revalidasi BST

Pada gambar 4 menunjukkan tentang perbandingan usia responden yang dibagi menjadi lima kelompok usia. Kelompok usia 31 - 40 tahun menduduki posisi tertinggi sebanyak 41,6\% ,diikuti dengan kelompok usia 21-30 tahun sebanyak $38.4 \%$, lalu selanjutnya diikuti oleh kelompok usia 41-50 tahun sebanyak 17,2\%. Kelompok usia keempat yaitu berada diusia lebih dari 50 tahun dan yang terkahir adalah kelompok usia kurang dari 20 tahun. Rata-rata tertinggi usia responden berada di usia produktif untuk bekerja diatas kapal, sedangkann terendah berada dibawah usia 20 tahun karena masih belum banyak yang berlayar dan beberapa masih mengikuti pendidikan dan pelatihan.

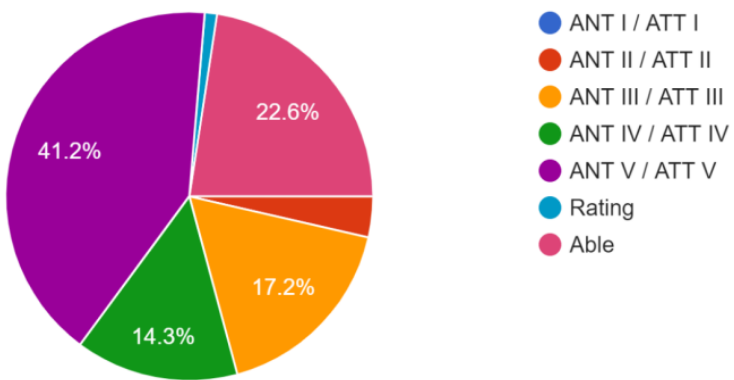

Gambar 5. Diagram Jenis Ijazah Kepelautan Peserta Revalidasi BST

Pada gambar 5 menunjukkan tentang ijasah terakhir yang dimiliki oleh responden. Posisi tertinggi sebanyak 41,2\% memiliki ijazah ANT/ATT V, lalu sebanyak $22.6 \%$ memiliki ijazah Able diikuti oleh ijazah ANT /ATT III dan ANT/ATT IV. Responden yang memiliki ijazah ANT/ATT kelas II dan kelas I menduduki peringkat terendah. 


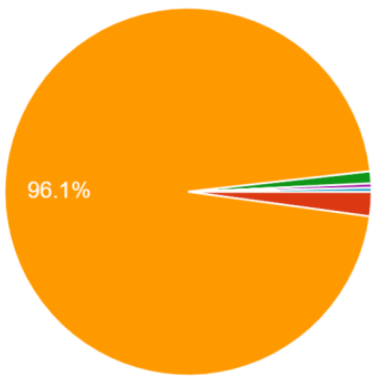

PNS/TNI/POLRI

Swasta/Wiraswasta

Pelaut

Pelajar/Mahasiswa

Swasta

Pelaut

Gambar 6. Diagram Pekerjaan Peserta Revalidasi BST

Pada gambar 6 menunjukkan tentang jenis pekerjaan responden dan sangat terlihat sekali bahwa pekerjaan dari responden sebagian besar adalah pelaut sebanyak $96.1 \%$. Lalu sisanya secara berturut-turut pekerjaan responden yaitu sebagai pekerja di perusahaan swasta/wiraswasta, pelajar/mahasiswa, dan PNS/TNI/POLRI. Sebaran kuesioner memang telah dikhususkan untuk dibagikan kepada para pelaut dan peserta diklat yang sedang mengambil diklat keterampilan.

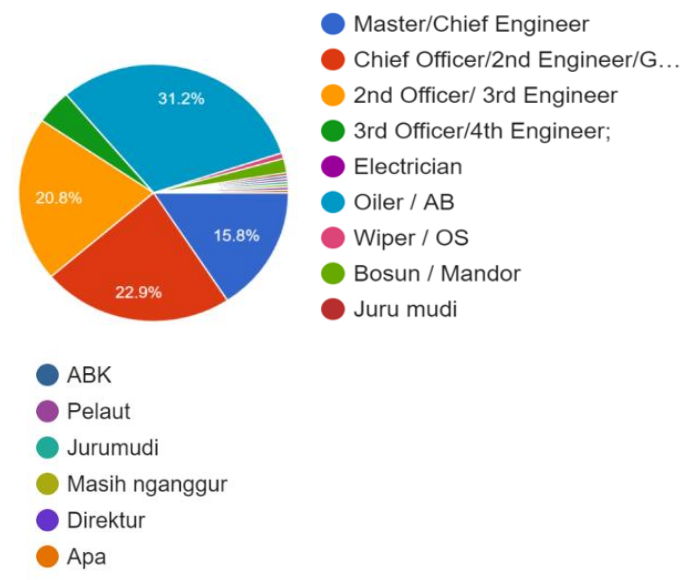

\section{Gambar 7. Diagram Posisi Peserta Revalidasi}

BST di atas Kapal

Pada gambar 7 diatas menunjukkan tentang posisi pekerjaan responden di atas kapal ataupun di perusahaan bagi yang bekerja di darat. Sebanyak 31,2\%adalah responden yang menempati posisi sebagai oiler/AB diatas kapal diikuti oleh posisi Chief Officer/second Engineer sebanyak $22.9 \%$ lalu oleh posisi second officer/third engineer sebanyak $20.8 \%$ dan posisi management level atau Master \&Chief Engineeer sebangayk $15.8 \%$. Sebagian dari para responden juga ada yang berprofesi sebagau Direktur di perusahaan pelayaran.

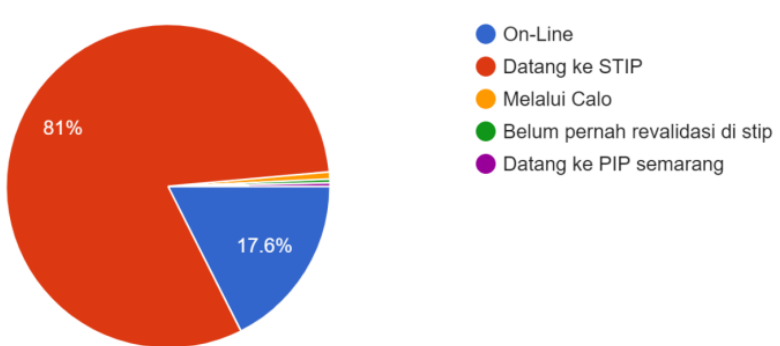

Gambar 8. Diagram Cara Peserta Melakukan Revalidasi BST

Pada gambar 8 menunjukkan tentang bagaimana para presponden melakukan revalidasi. Pilihan untuk datang ke STIP merupakan pilihan utama yang dilakukan oleh responden sebanyak $81 \%$. Untuk mereka yang tidak memilih datang ke STIP,maka dapat melakukan pendaftaran melalui online sebanyak 17,6\%. Seperti diketahui, STIP saat ini telah menyediakan ruang bagi para pelaut yang ingin mendaftar secara online melalui website resmi STIP dan dengan cara ini dianggap efektif terutama untuk menjangkau orang-orang yang berada diluar pulau Jawa ataupun yang masih berada diatas kapal.

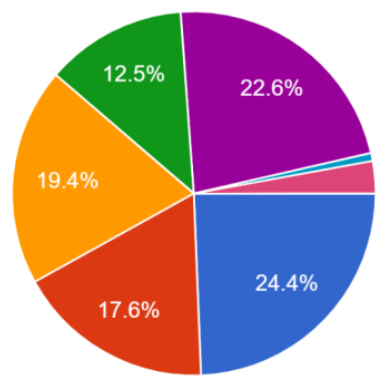

$$
\begin{aligned}
& \text { Jabodetabek } \\
& \text { Pulau Jawa } \\
& \text { Pulau Sumatera } \\
& \text { Pulau Kalimantan } \\
& \text { Pulau Sulawesi } \\
& \text { Papua } \\
& \text { NTB, NTT dan sekitarnya }
\end{aligned}
$$

Gambar 9. Diagram Lokasi Tempat Tinggal Peserta Revalidasi BST

Pada gambar 9 menunjukkan peta sebaran lokasi tempat tinggal para responden, yaitu berada di Jabodetabek (Jakarta,Bogor,Depok,Tangerang, Bekasi) sebanyak 24.4\%. Untuk pelaut yang berada di luar Jabodetabek terdiri dari pelaut yang berdomisili di Pulau Sulawesi sebanyak 22.6\%, di Pulau Sumatera sebanyak 19,45, di Nusa Tenggara Barat, Nusa Tenggara Timur dan sekitarnya sebanyak $17,6 \%$ dan sebanyak $12,5 \%$ berada di Pulau Kalimantan. Anemo masyarakat dari luar pulau Jawa untuk mengenyam pendidikan di STIP ternyata sangat besar meski di beberapa pulau sebenarnya juga sudah tempat diklat serupa yang berada di Kementerian Perhubungan. 


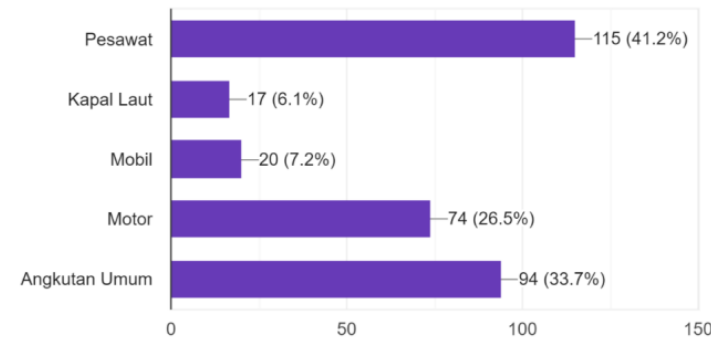

Gambar 10. Diagram Transportasi yang

Digunakan Peserta Revalidasi BST ke STIP

Pada gambar 10 menunjukkan tentang moda atau alat transportasi yang digunakan oleh responden unyuk menuju ke STIP. Prosentase terbesar menggunakan moda transportasi pesawat yaitu sebanyak $41,2 \%$, hal ini berarti banyak dari para responden yang berasal dari luar Jakarta. Lalu diikuti oleh peserta yang menggunakan angkutan umum seperti Trans Jakarta, angkot, dan ojeg online dengna prosentase sebesar $33.7 \%$. Bagi para peserta yang mungkin berada/tinggal di wilayah Jabodetabek memungkinkan sekali bagi mereka untuk datang menunju STIP dengna menggunakan moda trasnportasi motor $(26.5 \%$ dan mobil (7.2\%). Jumlah prosentase terkecil yaitu sebanyak $6,1 \%$ merupakan trasportasi dengan kapal laut yang digunakan oleh para responden untuk dapat datang ke STIP. Kondisi ini umumnya hanya bagi sebagian orang yang tinggal di daerah yang sulit dijangkau melalui transportsi darat dan laut.

279 responses
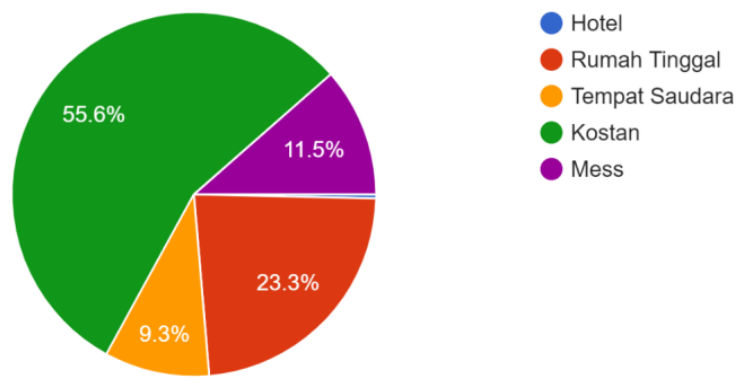

Gambar 11. Diagram Akomodasi/Tempat

Tinggal Peserta Revalidasi BST

Pada gambar 11 menunjukkan tentang jenis pekerjaan responden dan sangat terlihat sekali bahwa pekerjaan dari responden sebagian besar adalah pelaut sebanyak 96.1\%. Lalu sisanya secara berturut-turut pekerjaan responden yaitu sebagai pekerja di perusahaan swasta/wiraswasta, pelajar/mahasiswa, dan PNS/TNI/POLRI. Sebaran kuesioner memang telah dikhususkan untuk dibagikan kepada para pelaut dan peserta diklat yang sedang mengambil diklat keterampilan.
Berikut ini disajikan persentase indikatorindikator dalam tiap dimensi.

A. Pelayanan keselamatan

1. Fasilitas keselamatan peserta diklat dari lokasi tempat tinggal ke STIP

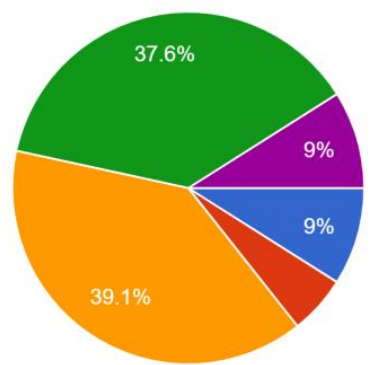

Tidak Terjamin

Kurang Terjamin

Biasa Saja

- Terjamin

Sangat Terjamin

Gambar 12. Diagram Keselamatan Peserta

Diklat dari Lokasi Tempat Tinggal ke STIP

Pada gambar 12 menunjukkan tentang fasilitas keselamatan peserta diklat dari lokasi tempat tinggal ke STIP.Sebanyak 39,1\% responden menyatakan bahwa fasilitas keselamatan yang mereka gunakan biasa saja, sedangkan $37.6 \%$ menyatakan terjamin. Kondisi ini berkaitan dengan jenis transportasi yang mereka gunakan dan tingkat kesadaran pribadi terhadap alat keselamatan.

2. Ketersediaan peralatan di STIP untuk kondisi darurat seperti alat pemadam kebakaran, petunjuk jalur evakuasi, titik kumpul evakuasi dan nomor telepon darurat

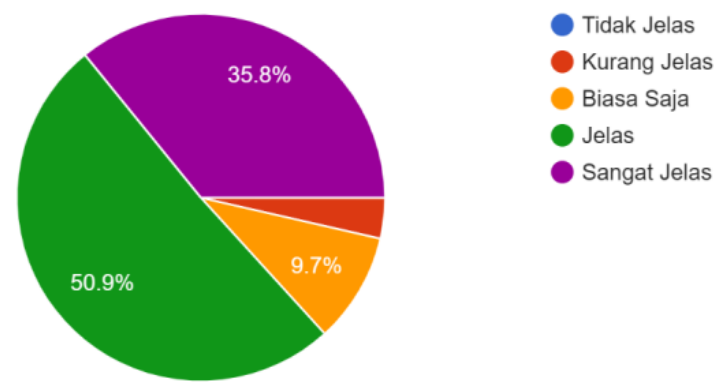

Gambar 13 Diagram Fasilitas Keselamatan

Pada gambar 13 menunjukkan tentang ketersediaan alat keselamtan di lingkungan STIP. Beberapa petunjuk yang dipasang di sekitar STIP khususnya area pelayanan dapat memudahkan peserta dalam menemukan sesuatu. Sebanyak $50.9 \%$ responden menyatakan alat dan petunjuk keselamatan telah jelas keberadaan dan fungsinya bagi mereka, bahkan sebanyak $35.8 \%$ responden menyatakan sangat jelas.

3. Ketersediaan informasi dan fasilitas kesehatan seperti ruang kesehatan, $\mathrm{P} 3 \mathrm{~K}$, dan petugas kesehatan di STIP 


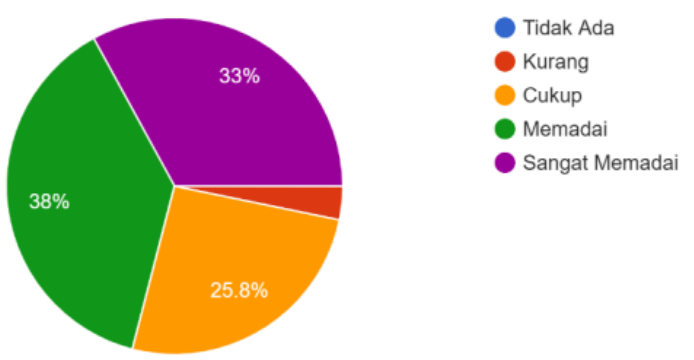

Gambar 14. Diagram Ketersediaan Informasi dan Fasilitas Kesehatan

Pada gambar 14 menunjukkan tentang ketersediaan informasi dan fasilitas kesehatan di STIP terkait dengan pelayanan bagi para pelaut. Sebanyak $38 \%$ responden menyatakan bahwa ketersediaan informasi sudah memadai.

B. Pelayanan ketepatan waktu

4. Antrian di ruang tunggu sesuai dengan waktu tunggu

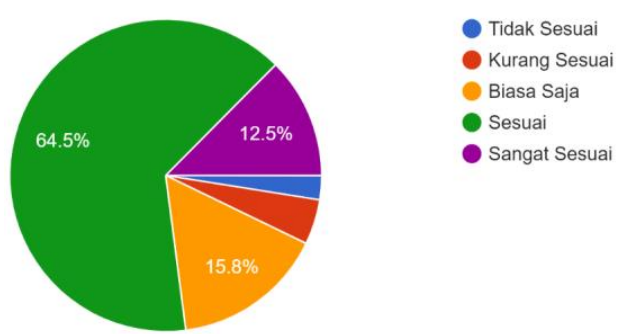

Gambar 15. Diagram Kesesuaian Antrian di Ruang Tunggu

Pada gambar 15 menunjukkan tentang kesesuaian antrain di ruang tunggu dengan waktu tunggu di loket pelayanan. Didapati bahwa sebanyak $64,5 \%$ responden menyatakan sudah sesuai, sebanyak $15.8 \%$ dan sebanyak $12,5 \%$ menyatakan sangat sesuai .

5. Proses layanan pendaftaran revalidasi cepat
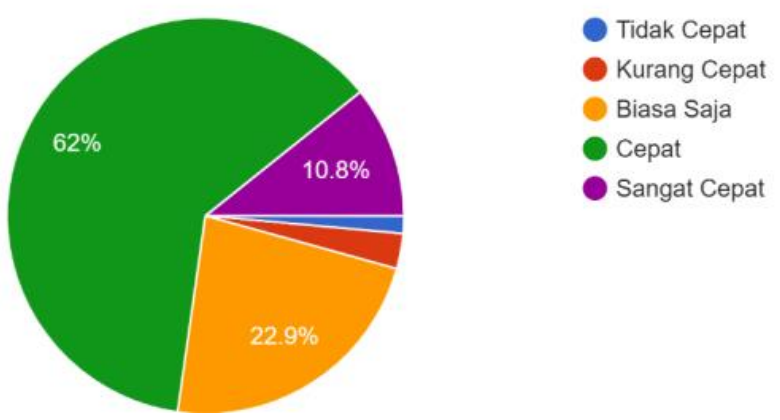

Gambar 16. Diagram Kecepatan Proses

Pendaftaran Revalidasi di STIP

Pada gambar 16 menunjukkan tentang kecepatan proses pendaftaran revalidasi di STIP dan hasil menunjukkan sebanyak $62 \%$ responden menyatakan layanan revalidasi dilaksanakan dengan cepat. Sebanyak 22,9\% responden menyatakan layanan revalidasi terlaksana biasa saja dan hanya $10,8 \%$ yang menyatakan layanan revalidasi sangat cepat.
6. Proses pembayaran revalidasi cepat

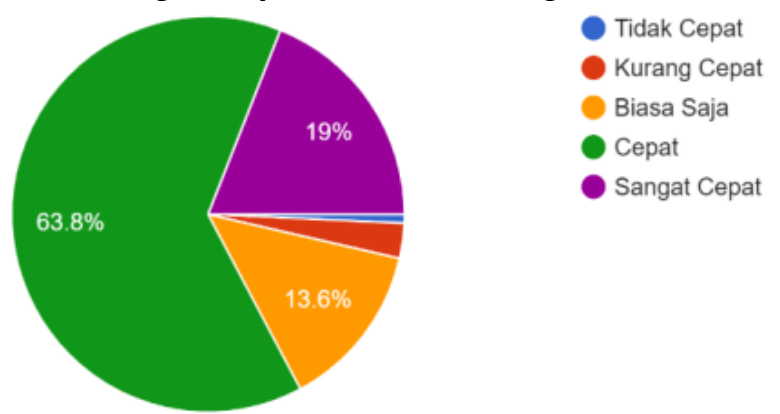

Gambar 17. Diagram Kecepatan Proses

Pembayaran Revalidasi

Pada gambar 17 menunjukkan tentang proses pembayaran revalidasi di STIP dan hasil menunjukkan sebanyak $63,8 \%$ responden menyatakan proses proses pembayaran revalidasi dilaksanakan dengan cepat. Sebanyak 13,6\% responden menyatakan layanan revalidasi terlaksana biasa saja dan $19 \%$ yang menyatakan layanan revalidasi sangat cepat.

7. Proses pemeriksaan kesehatan berlangsung tepat waktu
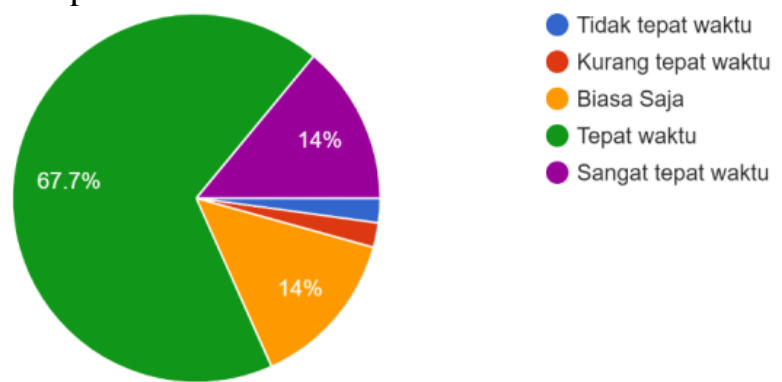

Gambar 18. Diagram Ketepatan Waktu

Pemeriksaan Kesehatan

Pada gambar 18 menunjukkan tentang proses pemeriksaan kesehatan di STIP dan hasil menunjukkan sebanyak $67,7 \%$ responden menyatakan proses proses pemeriksaan kesehatan berlangsung tepat waktu. Kondisi yang sama terjadi untuk proses pemeriksaan kesehatan yang berlangsung dengan sangat tepat waktu dan proses yang biasa saja yaitu sebanyak $14 \%$.

8. Proses verifikasi berlangsung cepat

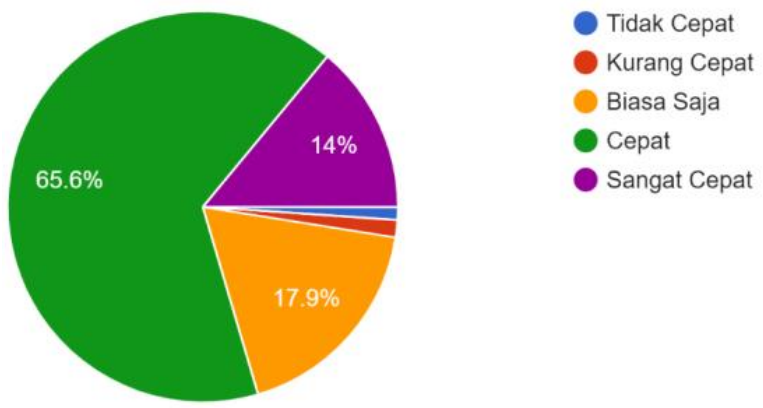

Gambar 19. Diagram Kecepatan Verifikasi

Pada gambar 19 menunjukkan tentang proses kecepatan dalam proses verifikasi di STIP dan hasil menunjukkan sebanyak $65,5 \%$ responden menyatakan proses proses verifikasi berlangsung 
cepat. Lalu sebanyak 17,9\% menyatakan biasa saja dan $14 \%$ menyatakan proses verifikasi sangat cepat.

C. Pelayanan Akurasi Pelayanan

9. Kemudahan mendapatkan informasi sesuai tujuan pelayanan yang diinginkan

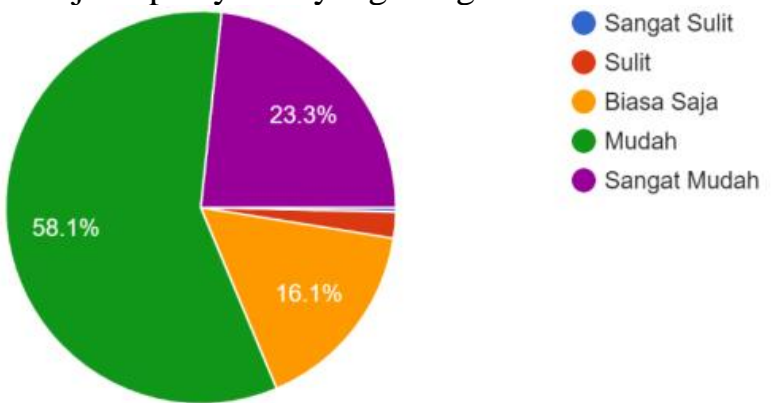

Gambar 20 Diagram Kemudahan Informasi Pelayanan

Pada gambar 20 menunjukkan tentang kemudahan informasi pelayanan di STIP dan hasil menunjukkan sebanyak $58,1 \%$ responden menyatakan mudah dalam mendapatkan informasi pelayanan di STIP, sebanyak $23,3 \%$ responden menyatakan sangat mudah dan $16,1 \%$ menyatakan biasa saja.

10. Ketersediaan informasi alur layanan revalidasi
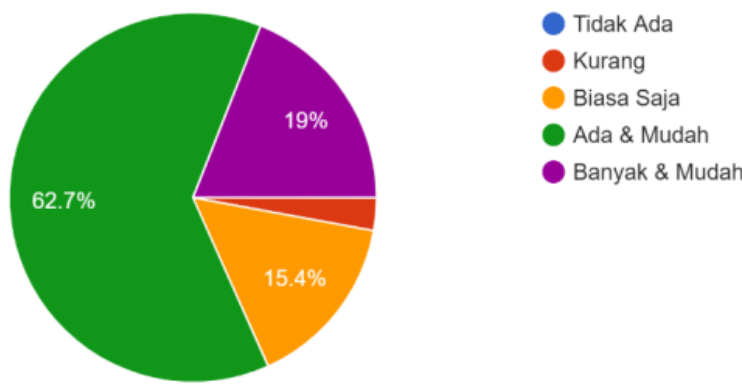

Gambar 20. Diagram Ketersediaan Informasi Alur Layanan Revalidasi

Pada gambar 20 menunjukkan tentang Ketersediaan Informasi Alur Layanan Revalidasi kemudahan informasi pelayanan di STIP dan hasil menunjukkan sebanyak $58,1 \%$ responden menyatakan mudah dalam mendapatkan informasi pelayanan di STIP, sebanyak $23,3 \%$ responden menyatakan sangat mudah dan $16,1 \%$ menyatakan biasa saja.

11. Ketersediaan informasi tentang harga layanan revalidasi dan waktu pelaksanaan

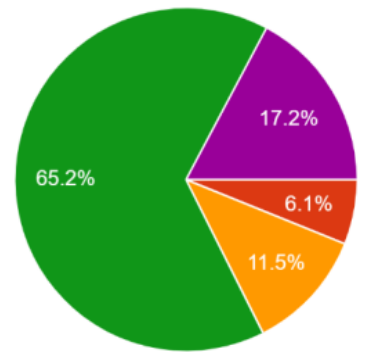

Gambar 21 Diagram Informasi Harga dan Waktu Pelaksanaan Revalidasi BST

Pada gambar 21 menunjukkan tentang Ketersediaan Informasi Harga dan Waktu Pelaksanaan Revalidasi BST sebanyak 65,2\% menyatakan ada dan mudah untuk didapatkan. Sebanyak $17,2 \%$ repsonden menyatakan informasi yang tersedia banyak dan mudah didapatkan. Sedangkan $11,5 \%$ responden menyatakan biasa saja. Informasi yang tersedia di STIP disediakan melalui online di website, dan tersedia pula pada loket pelayanan di STIP.

C. Pelayanan Kenyamanan di Area Loket Pelayanan

12.Kecukupan kapasitas ruang tunggu di loket pelayanan

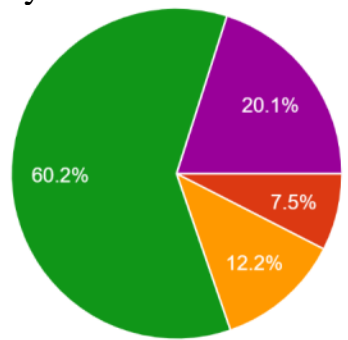

Sangat Kurang

Kurang

Biasa Saja

Memadai

Sangat Memadai

Gambar 22. Diagram Kecukupan Kapasitas Ruang Tunggu

Pada gambar 22 menunjukkan tentang kecukupan ruang runggu di loket pelayanan STIP. Sebanyak $60,2 \%$ responden menyatkaan memadai, $20,1 \%$ responden menyatakan sangat memadai dan $12,2 \%$ menyatakan cukup atau biasa saja. Area ruang tunggu di loket STIP memang disediakan banyak dan disesuaikan dengan kebutuhan jenis layanan.

13. Ketersediaan mesin antrian pada loket pelayanan
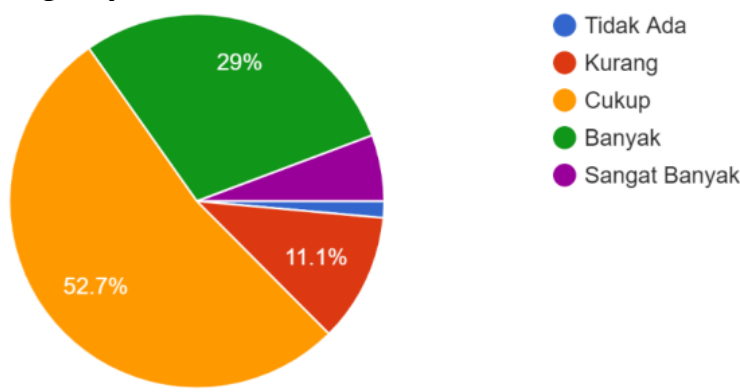

Gambar 23 Diagram Ketersediaan Mesin Antrian di Loket Pelayanan

Pada gambar 23 menunjukkan tentang Ketersediaan Mesin Antrian di Loket Pelayanan yang jumlahnya dinyatakan cukup oleh responden sebanyak $52,7 \%$. Beberapa diantara responden menyatakan banyak (29\%) dan sisanya $11,1 \%$ menyatakan kurang.

14. Ketersediaan toilet di area loket pelayanan 

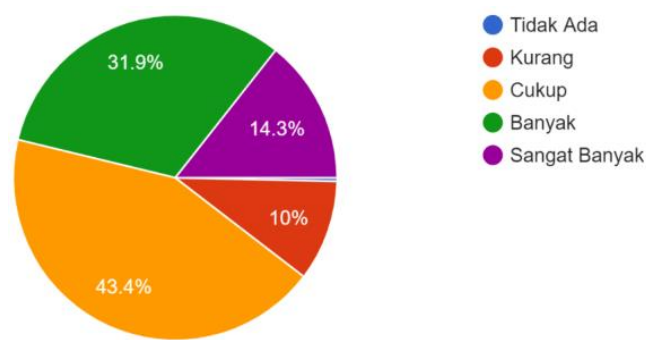

Gambar 24. Diagram Ketersediaan Toilet di Area Loket Pelayanan

Pada gambar 24 menunjukkan tentang Ketersediaan Mesin Antrian di Loket Pelayanan yang jumlahnya dinyatakan cukup oleh responden sebanyak $52,7 \%$. Beberapa diantara responden menyatakan banyak (29\%) dan sisanya $11,1 \%$ menyatakan kurang.

15. Kualitas kebersihan faslitas toilet di area loket pelayanan

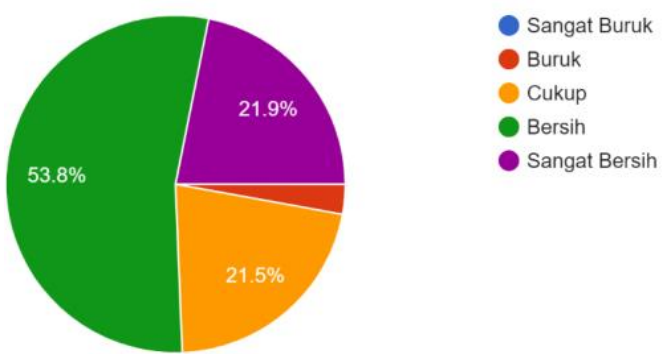

Gambar 25 Diagram Kebersihan Fasilitas Toilet

Pada gambar 25 menunjukkan diagram tentang kebersihan fasilitas toilet di STIP yang dinyatakan bersih oleh 53,8\% responden. Sebanyak $21,9 \%$ responden menyatakan sangat bersih dan $21,5 \%$ menyatakan cukuo bersih.

16. Ketersediaan Tempat Ibadah

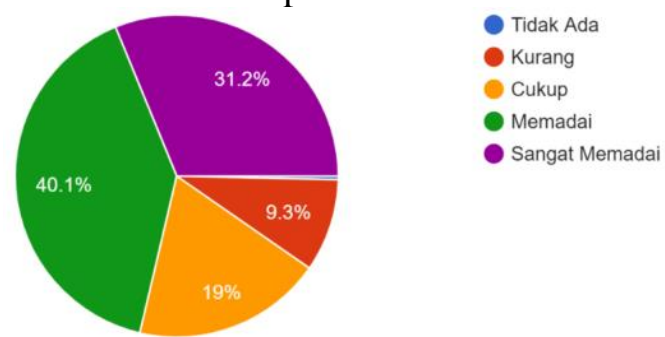

Gambar 26. Diagram Ketersediaan Tempat Ibadah

Pada gambar 26 menunjukkan diagram tentang ketersediaan tempat ibadah yang jumlahnya dinyatakan memadai oleh responden sebanyak 40,1\% . Beberapa diantara responden menyatakan sangat memadai $(31,2 \%)$ dan sisanya 19\% menyatakan cukup.

17. Ketersediaan fasilitas lampu penerangan di area ruang tunggu loket pelayanan

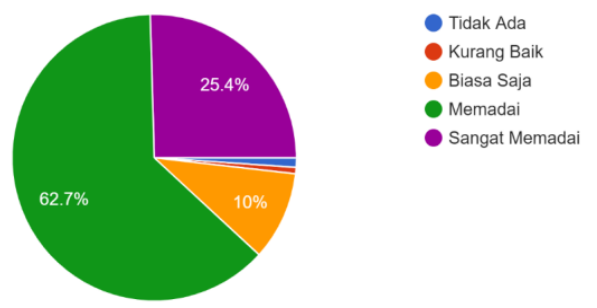

Gambar 27. Diagram Ketersediaan Fasilitas

Lampu Penerangan di Ruang Tunggu

Pada gambar 27 menunjukkan diagram tentang ketersediaan fasilitas lampu penerangan di ruang tunggu loket pelayanan STIP yang dinyatakan memadai oleh responden sebanyak $62,7 \%$. Beberapa diantara responden menyatakan sangat memadai $(25,4 \%)$ dan sisanya $10 \%$ menyatakan biasa saja.

18. Ketersediaan fasilitas kebersihan di area ruang tunggu loket pelayanan
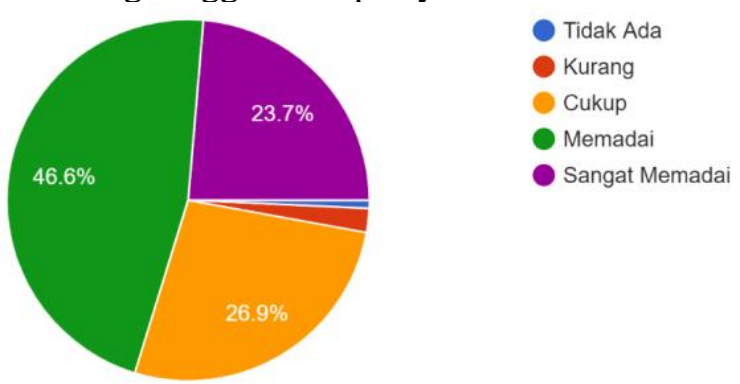

Gambar 28. Diagram Fasilitas Kebersihan di Area Ruang Tunggu

Pada gambar 28 menunjukkan diagram tentang Kebersihan di Area Ruang Tunggu yang jumlahnya dinyatakan memadai oleh responden sebanyak $46,6 \%$. Beberapa diantara responden menyatakan cukup (26,9\%) dan sisanya $23,7 \%$ menyatakan sangat memadai.

19.Ketersediaan fasilitas pengatur suhu/pendingin di di area ruang tunggu loket pelayanan
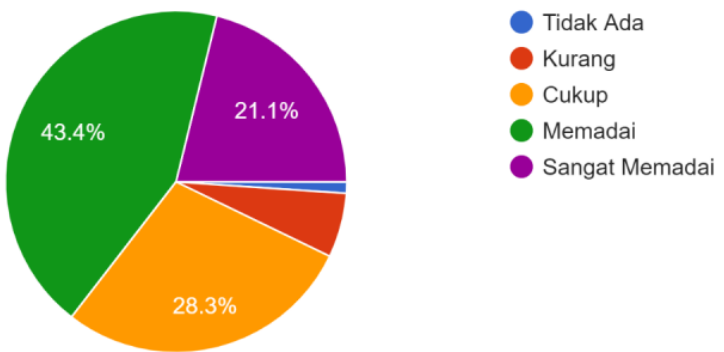

Gambar 29. Diagram Fasilitas Pengatur

Suhu/Pendingin di Area Ruang Tunggu

Pada gambar 29 menunjukkan diagram tentang Fasilitas Pengatur Suhu/Pendingin di Area Ruang Tunggu yang jumlahnya dinyatakan memadai oleh responden sebanyak 43,4 \%. Beberapa diantara responden menyatakan cukup $(28,3 \%)$ dan sisanya $21,1 \%$ menyatakan sangat memadai.

20. Ketersediaan ruang pelayanan kesehatan di area ruang tunggu loket pelayanan 


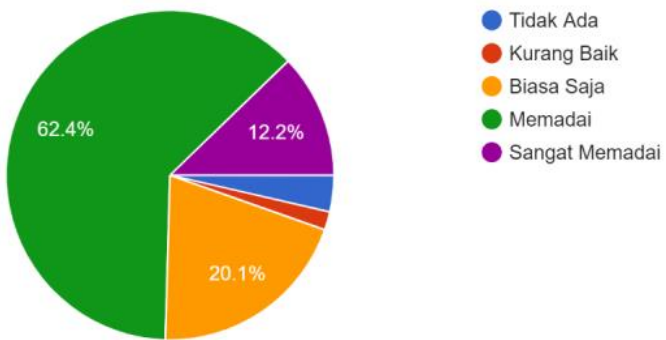

Gambar 30. Diagram Ketersediaan Ruang Pelayanan

Pada gambar 30 menunjukkan diagram tentang ketersediaan ruang pelayanan yang jumlahnya dinyatakan memadai oleh responden sebanyak $62,4 \%$. Beberapa diantara responden menyatakan biasa saja $(20,1 \%)$ dan sisanya $12,2 \%$ menyatakan sangat memadai .

21.Fasilitas area merokok di area ruang tunggu loket pelayanan

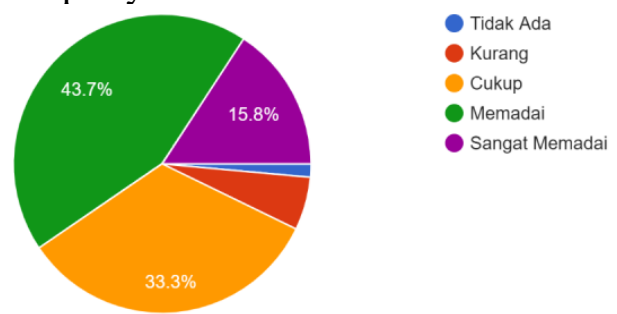

Gambar 31. Diagram Fasilitas Area Merokok di Ruang Tunggu

Pada gambar 31 menunjukkan diagram tentang Area Merokok di Ruang Tunggu di Area Ruang Tunggu yang jumlahnya dinyatakan memadai oleh responden sebanyak $43,7 \%$. Beberapa diantara responden menyatakan cukup $(33,3 \%)$ dan sisanya $15,8 \%$ menyatakan sangat memadai .

C. Pelayanan Kemudahan Di Loket Pelayanan

22.Ketersediaan informasi pelayanan di area ruang tunggu loket pelayanan

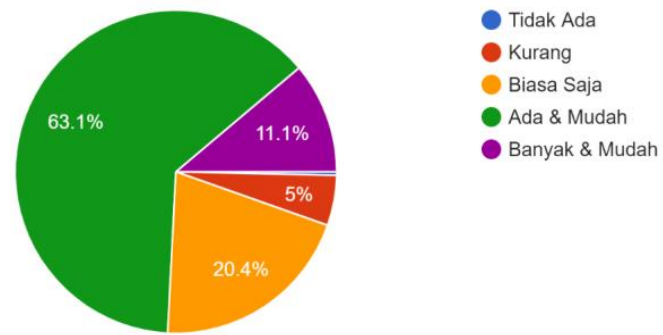

Gambar 32. Diagram Ketersediaan Informasi Pelayanan di Area Ruang Tunggu

Pada gambar 32 menunjukkan diagram tentang ketersediaan informasi pelayanan di area ruang tunggu Area Merokok di Ruang Tunggu di Area Ruang Tunggu yang jumlahnya dinyatakan tersedia/ada dan mudah oleh responden sebanyak $63,1 \%$. Beberapa diantara responden menyatakan biasa saja $(20,4 \%)$ dan sisanya $11,1 \%$ menyatakan banyak dan mudah .
23.Informasi gangguan perjalanan di area ruang tunggu loket pelayanan

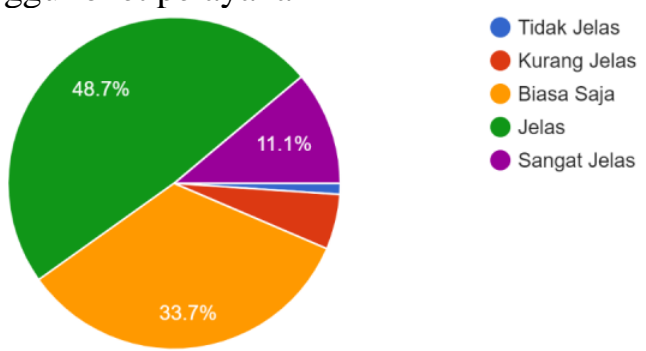

Gambar 33 Diagram Informasi Gangguan

Perjalanan di Area Ruang Tunggu Loket

Pada gambar 33 menunjukkan diagram tentang informasi Gangguan Perjalanan di Area Ruang Tunggu Loket yang dinyatakan jelas oleh responden sebanyak 48,7\%. Beberapa diantara responden menyatakan biasa saja $(33,7 \%)$ dan sisanya $11,1 \%$ menyatakan sangat jelas. Adapun informasi mengenai gangguan perjalanan ini terkait dengan kondisi lalu lintas dari dan menuju STIP.

\section{Jumlah customer service yang melayani} peserta di loket pelayanan

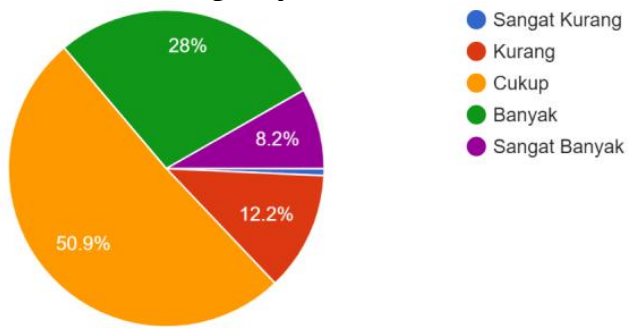

Gambar 34 Diagram Jumlah Customer Service

Pada gambar 34 menunjukkan diagram tentang Jumlah Customer Service yang melayani peserta di loket pelayanan. Sebanyak 50,9\% menyatakan cukup, beberapa diantara responden menyatakan banyak (28\%) dan sisanya $12,2 \%$ menyatakan kurang.

25. Jarak dari tempat pemberhentian angkutan umum ke loket pelayanan

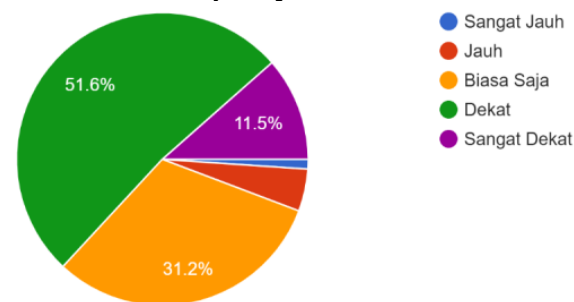

Gambar 35 Diagram Jarak Tempat

Pemberhentian Angkutan Umum ke Loket Pelayanan

Pada gambar 35 menunjukkan diagram tentang Jarak Tempat Pemberhentian Angkutan Umum ke Loket Pelayanan yang menyatakan dekat sebanyak 51,6\%, sebanyak 31,2\% menyatakan biasa saja, dan sisanya $11,5 \%$ menyatakan sangat dekat. 
26. Ketersediaan papan informasi atau petunjuk arah untuk fasilitas yang ada di area STIP

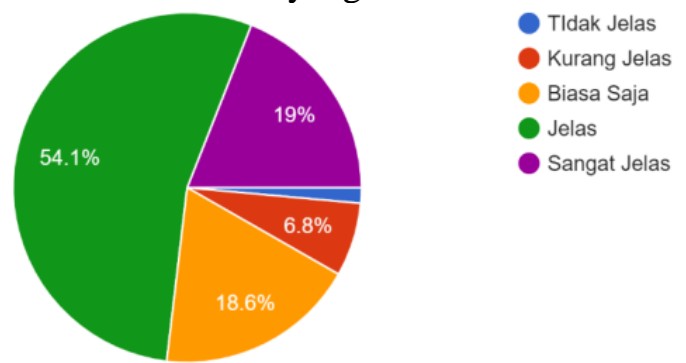

Gambar 36. Diagram Ketersediaan Papan

Informasi atau Petunjuk Arah di Area STIP

Pada gambar 36 menunjukkan diagram tentang Ketersediaan Papan Informasi atau Petunjuk Arah di Area STIP yang menyatakan jelas sebanyak 54,1\%, kemudian sebanyak $19 \%$ menyatakan sangat jelas dan 18,6\% menyatakan biasa saja.

27. Kejelasan informasi mengenai angkutan lanjutan yang ada di STIP

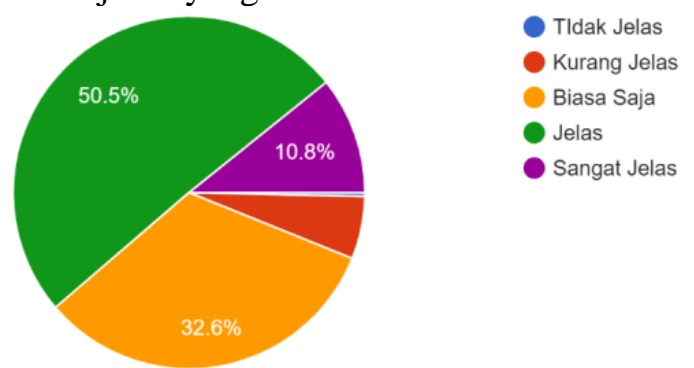

Gambar 37. Diagram Informasi Angkutan Umum Lanjutan di Area STIP

Pada gambar 37 menunjukkan diagram tentang Informasi Angkutan Umum Lanjutan di Area STIP yang menyatakan jelas sebanyak $50,5 \%$, kemudian sebanyak $32 \%$ menyatakan biasa saja dan $10,8 \%$ menyatakan biasa saja .

28. Ketersediaan fasilitas kemudahan untuk naik/turun penumpang di STIP (halte)

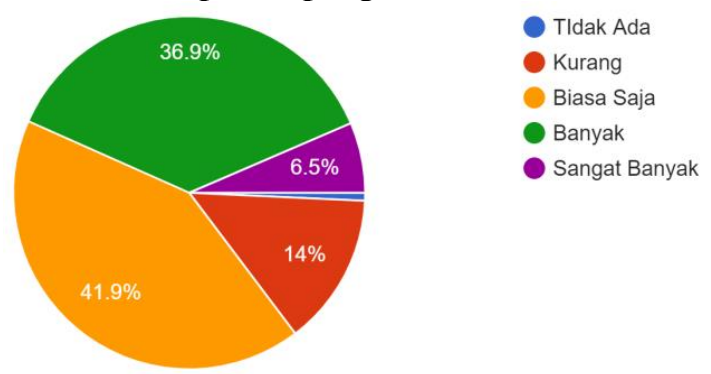

Gambar 38. Diagram Ketersediaan Fasilitas Naik/Turun Penumpang di Halte STIP

Pada gambar 38 menunjukkan diagram tentang Ketersediaan Fasilitas Naik/Turun Penumpang di Halte STIP yang menyatakan biasa saja sebanyak $41,9 \%$ responden. Lalu sebanyak $36,9 \%$ responden menyatakan banyak tersedia dan $14 \%$ responden menyatakan kurang tersedia. 29. Keberadaan calo di loket pelayanan STIP

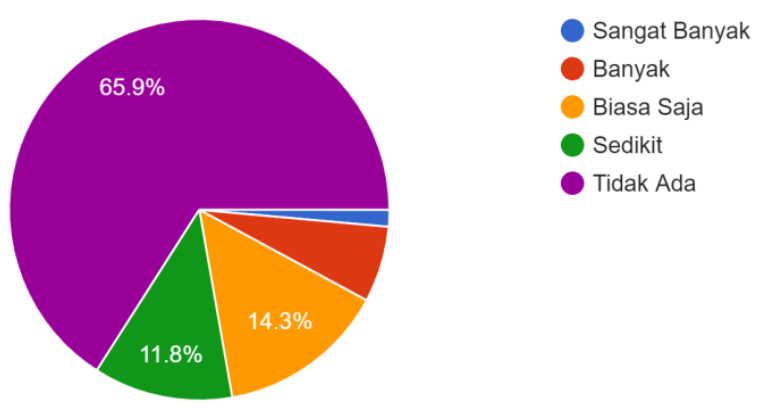

Gambar 39. Diagram Keberadaan Calo di Loket Pelayanan STIP

Pada gambar 39 menunjukkan diagram tentang keberadaan calo di loket pelayanan STIP yang menyatakan tidak ada sebanyak $65,9 \%$ responden. Lalu sebanyak $14,3 \%$ responden menyatakan biasa saja dan $11,8 \%$ responden menyatakan sedikit calo.

30. Ketersediaan tempat parkir kendaraan di STIP

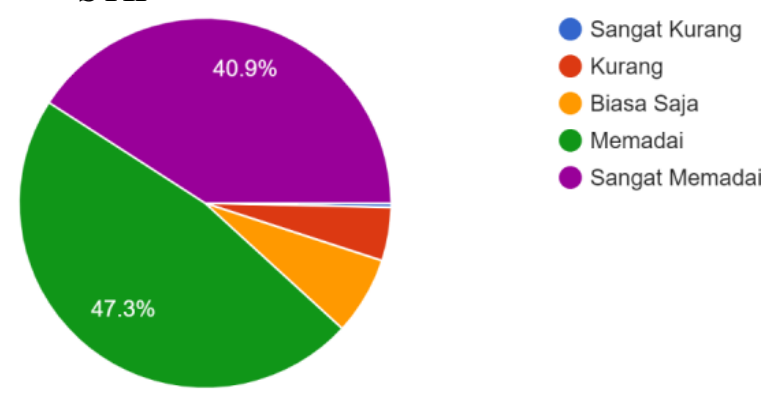

Gambar 40. Diagram Ketersediaan Tempat Parkir Kendaraan di STIP

Pada gambar 40 menunjukkan diagram tentang Ketersediaan tempat parkir kendaraan di STIP yang menyatakan memadai sebanyak $47,3 \%$ responden. Lalu sebanyak $40,9 \%$ responden menyatakan sangat memadai dan sisanya responden menyatakan biasa saja bahkan kurang.

C. Tanggapan rencana revalidasi dengan penilaian jarak jauh

31.Pemahaman konsep revalidasi dengan penilaian jarak jauh

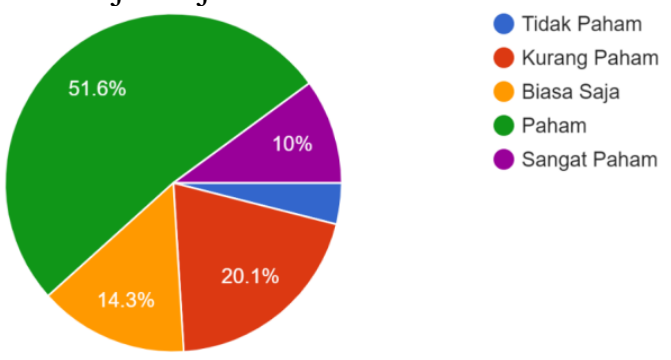

Gambar 41. Diagram pemahaman konsep revalidasi dengna penilaian jarak jauh

Pada gambar 41 menunjukkan tentang penilaian pemahaman peserta terkait konsep revalidasi jarak jauh. Sebanyak 51,6\% responden memahami konsep revalidasi jarak jauh, diikuti dengan $20,1 \%$ responden yang kurang memahami, $14,3 \%$ biasa saja atau netral, $10 \%$ responden 
sangat paham dan sisanya yaitu responden yang sama sekali tidak memahami terkait konsep revalidasi tersebut. Berdasarkan hasil diagram tersebut, dapat diketahui sebagian besar peserta diklat memahami konsep revalidasi jarak jauh.

32. Persetujuan bila revalidasi dilakukan secara online

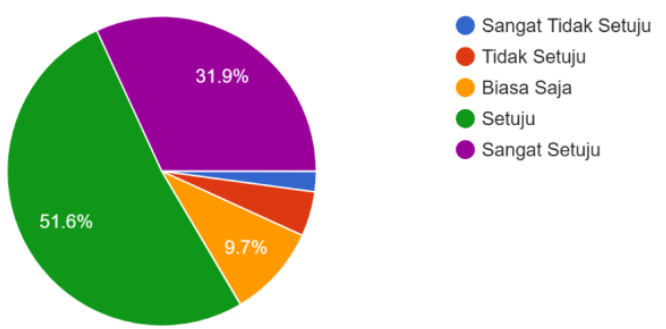

Gambar 42. Diagram persetujuan responden akan Revalidasi Online

Pada gambar 42 menunjukkan diagram penilaian pesertujuan peserta terkait revalidasi online menunjukkan $51,6 \%$ responden setuju dilakukannya revalidasi secara online, $31,9 \%$ sangat setuju, 9,7\% biasa saja atau netral, dan sisanya diikuti tidak setuju dan sangat tidak setuju. Berdasarkan hasil tersebut, sebagian besar responden setuju dilakukannya revalidasi secara online mengingat hal ini dapat memberikan kemudahan bagi peserta yang ingin merevalidasi sertifikat namun posisi masih berada di atas kapal. 33. Apakah anda merasa perlu untuk dilakukan penilaian revalidasi dengan jarak jauh

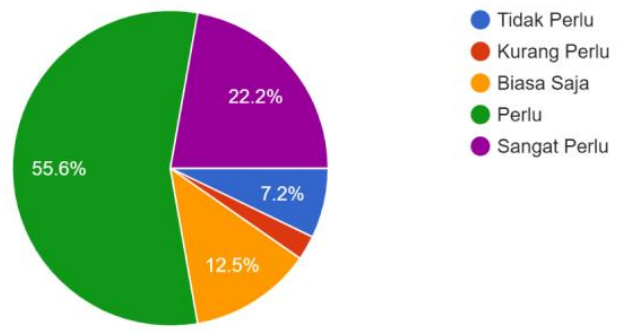

Gambar 43. Diagram penilaian revalidasi dengan jarak jauh

Pada gambar 43 diagram pendapat peserta terkait penilaian revalidasi jarak jauh, didapatkan hasil 55,6\% responden merasa perlu dilakukan penilaian revalidasi jarak jauh, diikuti $22,2 \%$ sangat perlu, $12,5 \%$ biasa saja atau netral, 7,2\% tidak perlu, dan sisanya kurang perlu. Berdasarkan hasil diagram tersebut dapat terlihat bahwa sebagian besar responden merasa perlu diadakannya penilaian revalidasi jarak jauh.

34. Kemudahan pelaksanaan revalidasi dilakukan dengan penilaian jarak jauh

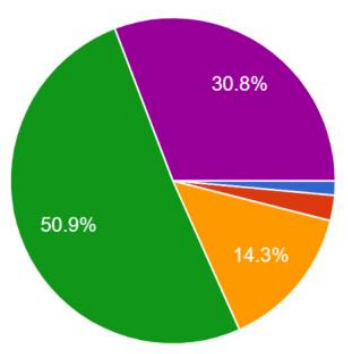

Sangat tidak dimudahkan

Tidak dimudahkan

Biasa Saja

Dimudahkan

- Sangat Dimudahkan

Gambar 44 Diagram kemudahan bila pelaksanaan revalidasi dengan penilaian jarak jauh

Pada gambar 44 diagram pendapat peserta terkait kemudahan revalidasi jarak jauh didapat hasil yaitu 50,9\% repsonden merasa dimudahkan bila pelaksanaan revalidasi dilakukan dengan penilaian jarak jauh, diikuti oleh $30,8 \%$ responden merasa sangat dimudahkan, $14,3 \%$ biasa saja atau netral, kemudian sisanya yaitu tidak dimudahkan dan sangat tidak dimudahkan. Berdasarkan hasil terbut dapat terlihat bahwa sebagian besar responden merasa dimudahkan jika dilaksanakan revalidasi dengan penilaian jarak jauh.

\section{Kemudahan Akses Teknologi}

35. Penggunaan internet secara umum

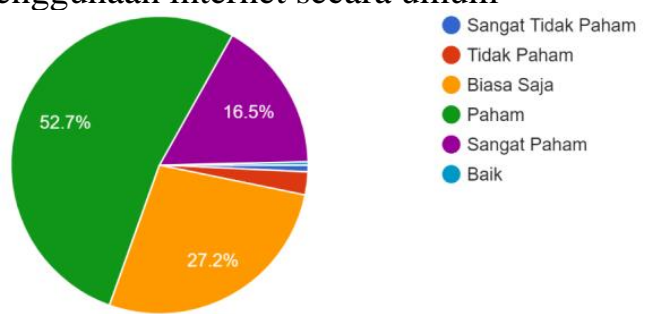

Gambar 45 Diagram pemahaman penggunaan internet secara umum

Gambar 45 diagram penggunaan internet oleh peserta revalidasi, berdasarkan hasil tersebut didapati bahwa $52,7 \%$ respondem memahami penggunaan internet secara umum, 27,2\% merasa biasa saja atau netral $16,5 \%$ sangat memahami penggunaan internet, kemudian diikuti dengan tidak paham dan sangat tidak paham. Berdasarkan hasil tersebut, dapat terlihat bahwa sebagian besar peserta memahami penggunaan internet secara umum.

36. Akses internet mudah di dapat di tempat tinggal

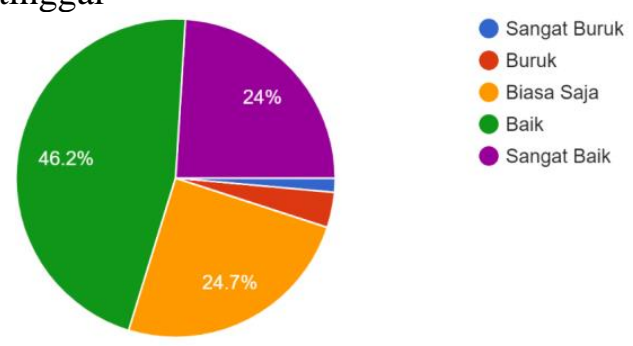

Gambar 46. Diagram akses internet responden

Pada gambar 46 diagram kemudahan 
mendapati akses internet di tempat tinggal peserta revalidasi, didapati hasil bahwa $46,2 \%$ responden merasa mudah mendapatkan akses internet di tempat tinggal mereka, 24,7\% merasa biasa saja atau netral, 24\% merasa sangat baik dalam mendapatkan akses internet, kemudian diikuti dengan buruk dan sangat buruk dalam mendapatkan akses internet di tempat tingga peserta.

37. Akses internet mudah di dapat bila di kapal

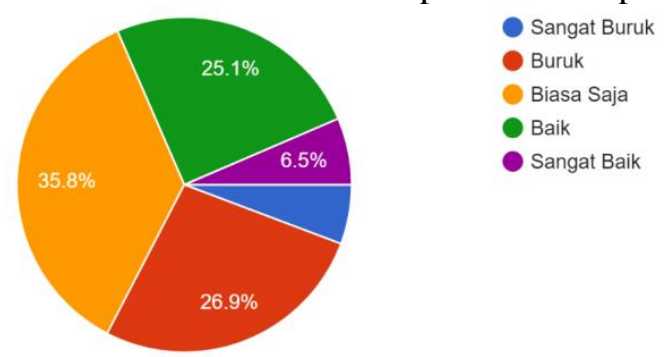

Gambar 47 Diagram akses internet responden di kapal

Pada gambar 47 diagram kemudahan akses internet di kapal, 35,8\% responden merasa biasa saja atau netral dalam mendapatkan akses internet di atas kapal, 26,9\% merasa buruk dalam mendapatkan akses internet diatas kapal, lalu diikuti $25,1 \%$ merasa baik, 6,5\% merasa sangat baik dan sisanya sangat buruk. Berdasarkan hasil diagram tersebut didapati bahwa sebagian responden tidak begitu banyak mendapatkan kemudahan akses internet di atas kapal mengingat kondisi di kapal yang sebagian besar berada jauh dari daratan sehingga akses internet menjadi kurang stabil sekalipun tersedia wifi di atas kapal. 38. Kesulitan mengoperasikan sistem google

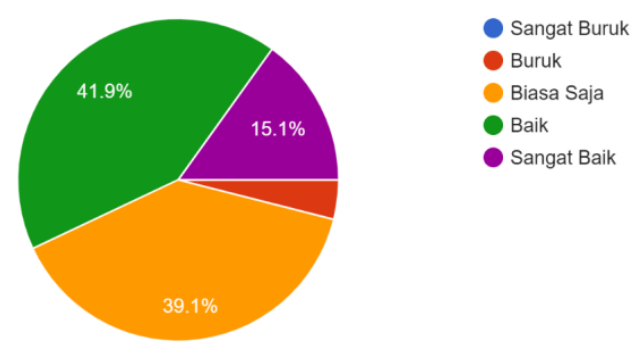

Gambar 48 Diagram Kesulitan pengoperasian system google

Pada gambar 48 diagram pendapat peserta terkait pengoperasian sistem google, didapati hasil 41,9\% merasa baik dalam pengoperasian sistem Google, 39,1\% merasa biasa saja atau netral, $15,1 \%$ merasa sangat baik, lalu diikuti dengan merasa buruk dalam pengoperasian sistem Google.Sebagian besar responden tidak ada masalah terkait pengoperasian sistem google.

39. Pembelian paket internet

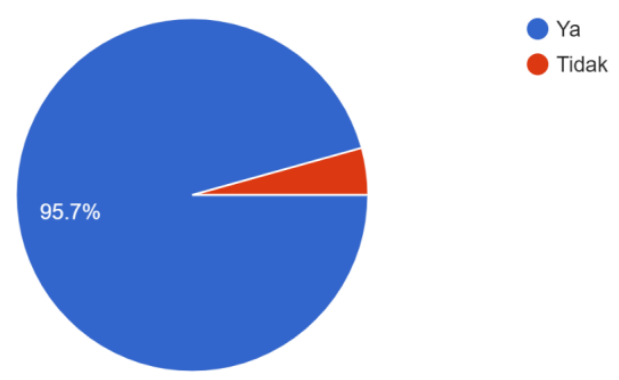

Gambar 49 Diagram pembelian paket internet oleh responden

Pada gambar 49 diagram peserta terkait pembelian paket Internet, berdaksarkan digram tersebut diketahui bahwa 95,7\% responden selalu membeli paket ineternet dan 4,3\% sisanya tidak membeli paket internet.

40. Penggunaan fasilitas wifi bila ingin menggunakan internet

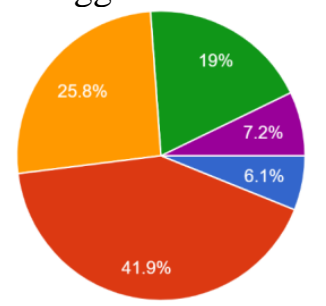

Sangat tidak mengandalkan

- Tidak mengandalkan

- Biasa Saja

- Mengandalkan

- Sangat mengandalkan

Gambar 50 Diagram penggunaan Wifi untuk Internet

Pada gambar 50 diagram penggunaan wifi bagi peserta revalidasi didapati bahwa $41,9 \%$ respondem tidak mengandalkan wifi, $25,8 \%$ biasa sajat atu netral, $19 \%$ mengandalkan penggunaan wifi, $7,2 \%$ sangat mengandalkan dan $6,1 \%$ sangat tidak mengandalkan. Berdasarkan diagram tersebut, sebagian besar responden tidak mengandalkan wifi untuk mengakses internet.

41. Kesulitan mengoperasikan internet

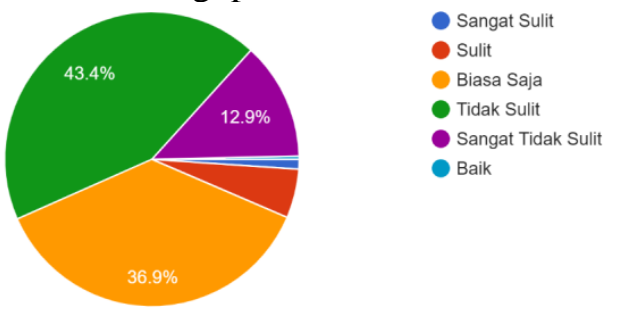

Gambar 51 Diagram kesulitan responden dalam mengoperasikan internet

Pada gambar 51 diagram terkait kesulitan pengoperasian internet bagi peserta revalidasi, sebanyak, 43,4\% merasa tidak kesulitan dalam mengoperasikan internet, $36,9 \%$ responden merasa biasa saja atau netral, kemudian 12,9\% responden merasa sangat tidak sulit dan diikuti oleh sulit dan sangat buah. 
42. Perkembangan teknologi handphone

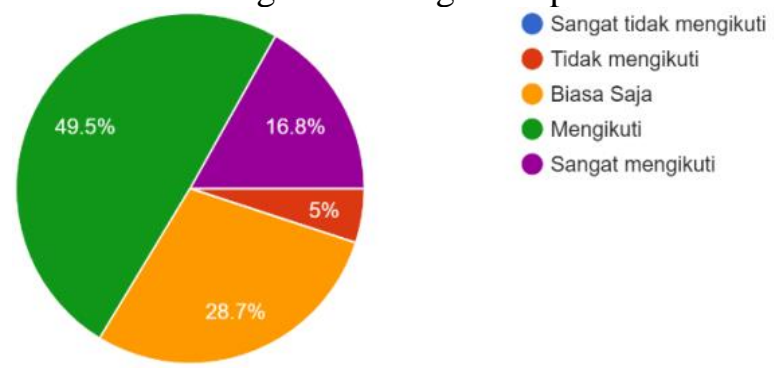

Gambar 52 Diagram keikutsertaan responden terhadap perkembangan teknologi Handphone

Pada gambar 52 diagram perkembangan teknologi yang diikuti peserta, didapati hasil $49,5 \%$ responden mengikuti perkembangan teknologi handphone, kemudian diikuti dengan $28,7 \%$ responden merasa biasa atau netral, lalu $16,8 \%$ responden sangat mengikuti dan $5 \%$ tidak mengikuti perkembangan teknologi handphone. Berdasarkan hasil tersebut, sebagian besar responden/peserta revalidasi mengikuti perkembangan teknologi handphone.

43. Pengguna handphone berjenis android

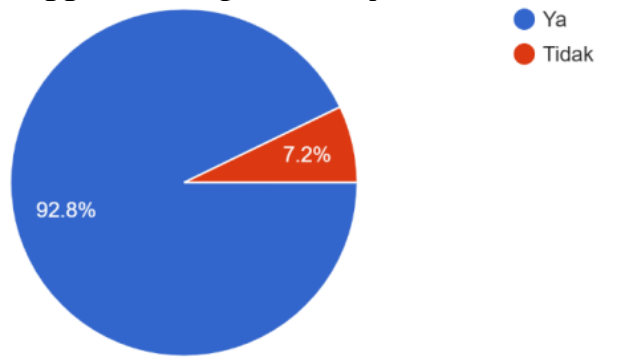

Gambar 53 Diagram penggunaan handphone android oleh Responden

Pada gambar 53 diagram penggunaan android oleh peserta revalidasi, didapati hasil 92,8\% peserta menggunakan handphone dengan sistem operasi android kemudian diikuti oleh $7,2 \%$ responden tidak menggunakan android.

44. Penggunaan handphone berjenis ios/apple

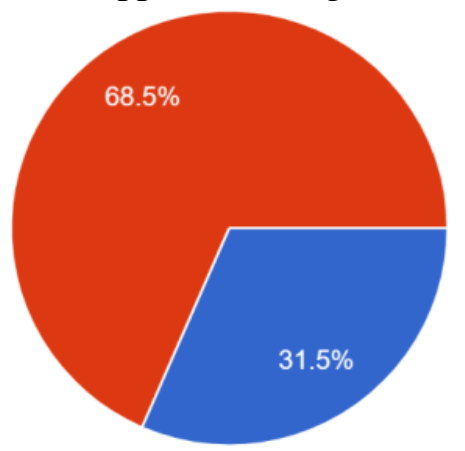

Gambar 54 Diagram penggunaan handphone berjenis IOS/APPLE

Pada gambar 54 diagram penggunaan Ios/Apple oleh peserta revalidasi, didapati hasil bahwa $68,5 \%$ peserta tidak menggunakan handphone dengan sistem operasi Ios/Apple dan $31,5 \%$ menggunakan Ios/Apple.
45. Penggunakn applikasi skype

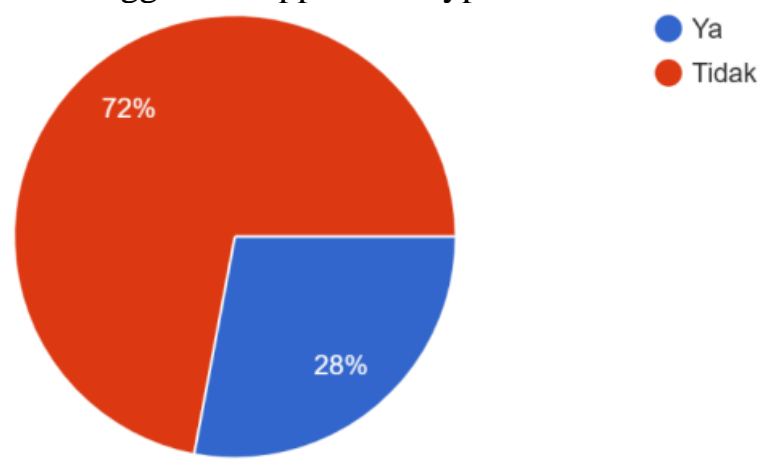

Gambar 55 Diagram penggunaan aplikasi Skype oleh Responden

Pada gambar 55 diagram penggunaan skype oleh peserta revalidasi, berdasarkan hasil tersebut didapati bahwa $72 \%$ responden tidak menggunakan aplikasi skype dan diikutin 28\% responden menggunakan aplikasi skype sebagai media komunikasi.

Dari data yang didapatkan diatas, dapat kita lihat bahwa pelayanan yang ada di STIP saat ini telah cukup baik, dari segi pelayanan, kenyamanan, ketersediaan informasi sudah memadai. Dari segi penerapan akan rencana revalidasi online didapati sebanyak 51,6\% responden mengharapkan adanya revalidasi online dan responden sebenarnya pun telah paham akan prinsip dari revalidasi online ini.

Sistem yang diharapkan dari model revalidasi online ini adalah sebuah sistem yang sifatnya mudah bagi para pengguna (user's friendly) sebab sebagian besar dari para pelaut yang dalam hal ini diwakilkan oleh para responden menggunakan media komunikasi handphone dengan sistem pengoperasian Android.

2. Model Pendaftaran Revalidasi Online

Mengikuti perkembangan tehnologi yang ada dan disesuaikan dengan kemampuan pelaut, maka peneliti mencoba membuat model pendaftaran revalidasi online semudah mungkin, tanpa harus merumitkan penggunanya. Model pendaftaran revalidasi online tersebut dapat dilihat melalui alur berikut ini:

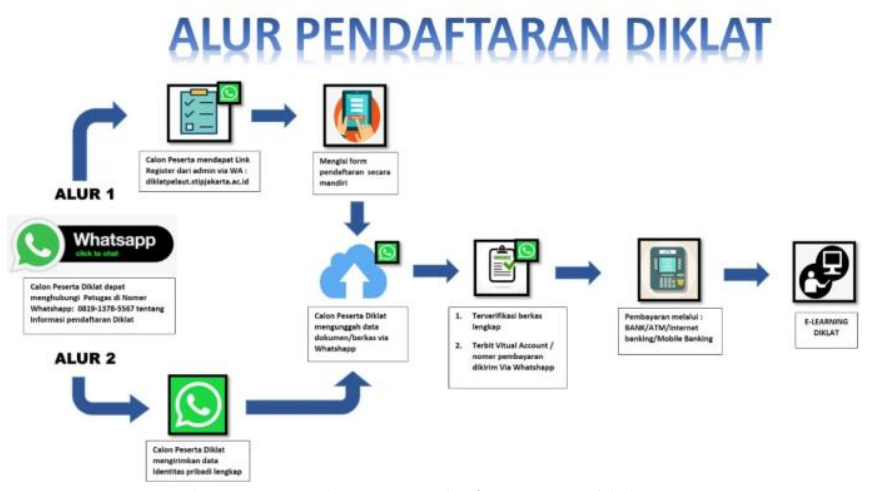

Gambar 56 Alur Pendaftaran Diklat STIP

Pada gambar 56 mengenai alur pendaftaran 
diklat yang dilaksanakan di STIP dapat dijelaskan sebagai berikut :

1) Alur 1

a. Calon peserta diklat dapat mendaftar melalui applikasi whatsapp customer service STIP

b. Setelah mendaftar melalui WA, maka calon peserta akanmendapat link register yang selanjutnya harus di buka oleh calon peserta

c. Pada link tersebut, peserta disediakan form pendaftarandan dokumen lain yang wajib diisi .

d. Setelah form dan dokumen tersebut diisi maka wajib di unggah kembali melalui WA Customer Service STIP untuk di verifikasi.

e. Petugas CS melakukan verifikasi form pendaftaran dan dokumen, apabila telah sesuai dan lengkap maka akan diterbitkan nomor Virtual Account sebagai dasar pembayaran diklat yang harus dibayarkan oleh calon peserta diklat .

f. Calon Peserta diklat membayarkan biaya diklat melalui Bank, dan bukti transfer/pembayaran dapat dikirimkan kembali kepada petugas CS.

g. Calon peserta diklat diinformasikan untuk jadwal pembelajaran yang dilakukan secara online dengan metode pembelajaran jarak jauh.

2) Alur 2

a. Calon peserta diklat menghubungi petugas CS menggunakan applikasi WA.

b. Calon peserta diklat mendaftar dengan memberikan data-data diri melalui WA customer service STIP

c. Petugas CS STIP membantu mendaftarkan calon peserta diklat melalui link pendaftaran yang tersedia .

d. Setelah form dan dokumen tersebut diisi maka calon peserta diklat mengunggah kembali melalui WA Customer Service STIP untuk di verifikasi.

e. Petugas CS melakukan verifikasi form pendaftaran dan dokumen, apabila telah sesuai dan lengkap maka akan diterbitkan nomor Virtual Account sebagai dasar pembayaran diklat yang harus dibayarkan oleh calon peserta diklat.

f. Calon Peserta diklat membayarkan biaya diklat melalui Bank, dan bukti transfer/pembayaran dapat dikirimkan kembali kepada petugas CS.

g. Calon peserta diklat diinformasikan untuk jadwal pembelajaran yang dilakukan secara online dengan metode pembelajaran jarak jauh.

Dengan kondisi tempat tinggal pelaut yang berada jauh dari kota Jakarta dan ditambah pula dengan kondisi karena situasi pandemik saat ini, maka ini STIP membuka jalur pendaftaran online yang dapat diakses dengan internet. Sistem pendaftaran dibuat semudah mungkin dengan cara para pelaut membuka link yang tersedia di website STIP. Link dapat diakses menggunakan handphone, maupun komputer (personal computer). Peserta diklat hanya tinggal mengunggah atau mengupload berkas/dokumen untuk persyaratan melalui sistem dan selanjunya akan diverifikasi oleh admin. Setelah verifikasi dilakukan maka peserta akan mendapatkan nomor Virtual account untuk melakukan pembayaran diklat melalui Bank. Selanjutnya hasil / bukti pembayaran dapat diupload melalui whatsapp yang dikirimkan ke admin dan akhirnya peserta akan diinfokan untuk jadwal pembelajaran online.

Begitu simpel dan mudah. Peserta tidak perlu hadir ke STIP , hanya tinggal memanfaatkan tehnologi yang ada. Untuk menjaga keaslian dari dokumen yang dilampirkan, peserta diwajikan mengisi surat pernyataan yang harus dikirimkanjuga kepada pihak penyelenggara.

\section{Model Evaluasi Revalidasi Online}

Untuk model evaluasi revalidasi online, peneliti mencoba mengembangkan dari sistem pembelajaran yang telah ada sebelumnya, yang dilakukan secara manual dengan tatap muka. Evaluasi dibuat dengan memanfaatkan sistem yang tersedia pada google form. Diakhir pembelajaran, peserta akan dikirimkan link untuk pengisian evaluasi.

Adapun isi dari link berupa nama peserta, periode diklat dan yang terutama berisikan beberapa soal atau pertanyaan terkait dengan diklat keterampilan yang diambil, dalam hal ini diklat BST (Basic Safety Training).

Berikut adalah contoh tampilan dari link tersebut :

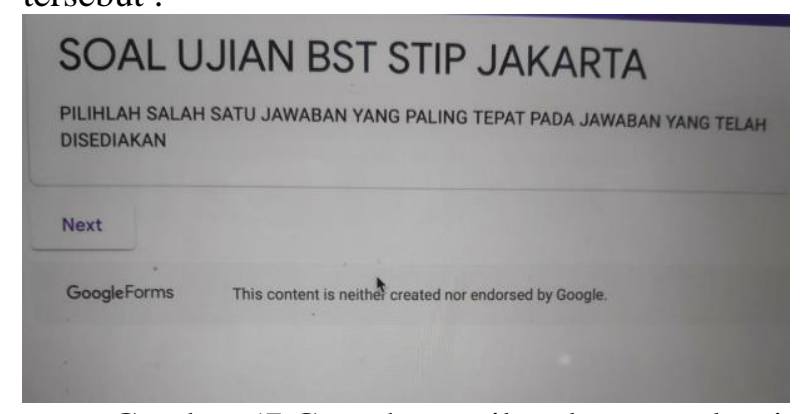

Gambar 57 Contoh tampilan depan evaluasi revalidasi online BST 


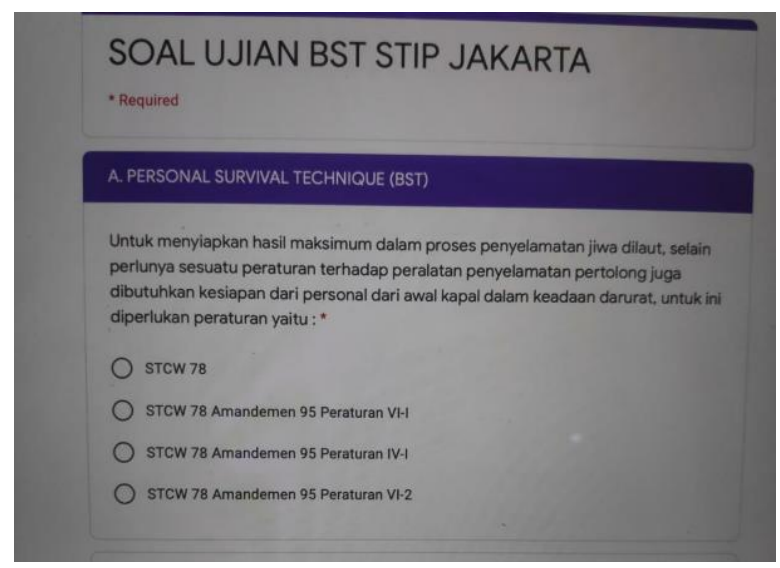

Gambar 58. Contoh pertanyaan evaluasi revalidasi online BST (1)

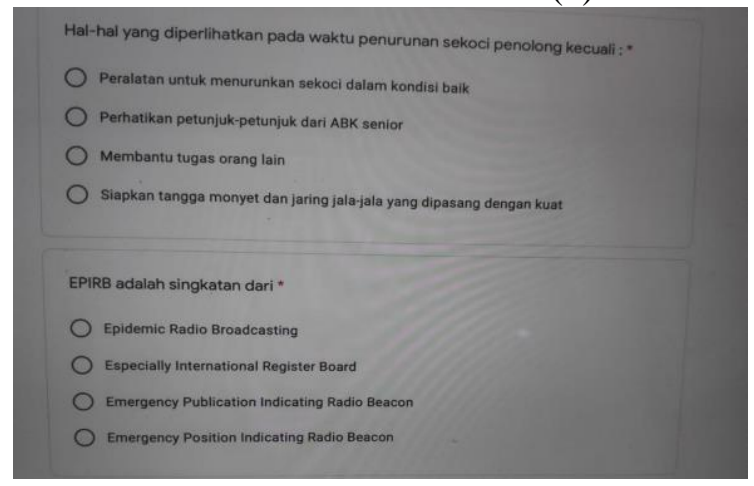

Gambar 59. Contoh tampilan depan evaluasi revalidasi online BST (2)

Pada gambar 57 merupakan contoh tampilan awal dari evaluasi revalidasi online. Peserta akan melihat tampilan ini dan selanjutnya akan diminta untuk mengisi nama dan periode diklat. Proses ini dapat dilakukan melalui handphone dan komputer.

Pada gambar 58 merupakan contoh tampilan dari pertanyaan-pertanyaan untuk evaluasi revalidasi online. Perserta dapat memilih jawaban yang benar dengan memililih/meng-click jawaban yang dianggap benar.

Link ini akan langsung terhubung kepada pelaksana diklat, dan hasilnya dapat langsung dicek oleh para petugas/pelaksana kegiatan belajar-mengajar melalui sistem. Dengan sistem ini tentu sangat memudahkan para pelaksana diklat di lapangan dan sangat menghemat waktu. Selain itu,para peserta diklat juga tidak perlu datang atau hadir ke STIP ,atau harus turun dari kapal hanya untuk melakukan revalidasi.

\section{KESIMPULAN}

Berdasarkan penjabaran yang telah peneliti kemukakan pada sebelumnya, dapat disimpulkan sebagai berikut:

1. Pelaksanaan revalidasi sertifikat BSTsecara online di STIP dapat dilaksanakan dengan tetap memperhatikan ketentuan persyaratan mulai dari proses pendaftaran, evaluasi sampai dengan penerbitan sertifikat revalidasi.

2. Legalitas sertifikat revalidasi sertifikat yang dilakukan dengan jarak jauh adalah sama dan legal seperti sertifikat revalidasi yang dilakukan secara reguler. Seluruh rangkaian proses dilakukan sesuai SOP yang berlaku dan tidak memberikan celah untuk dilakukannya tindakan penipuan.

3. Perlu dibuatkan applikasi berbasis website resmi yang merangkum fitur-fitur dari hasil penelitian para Dosen, khususnya untuk penelitian yang mengangkat mengenai perkembangan dalam sertifikasi masingmasing diklat keterampilan pelaut.

Penelitian yang dilakukan saat ini hanya membahas satu jenis diklat keterampilan yang nantinya diharapkan dapat memberikan masukan berarti bagi para regulator khususnya di Direktorat Jenderal Perhubungan Laut, Kementerian Perhubungan. Oleh karena itu peneliti mencoba memberikan saran :

1. Perlu adanya pembahasan lanjutan mengenai sistem prosedur pelaksanaan diklat secara online / daring dengan penerapan metodemetode tertentu menyesuaikan dengan perkembangan jaman saat ini.

2. Pentingnya pemberian materi mengenai Tehnologi Informasi bagi seluruh peserta diklat keterampilan dan diklat peningkatan pelaut di seluruh Indonesia terutama bagi para pelaut-pelaut pada tingkat dasar.

3. Pentingnya pemberian anggaran yang cukup besar kepada masing-masing UPT (Unit Pelaksana Teknis) Diklat di bawah BPSDM Perhubungan untuk pengembangan dan peningkatan sistem informasi manajemen dan tehnologi informasi sehingga setiap UPT dapat bersiap dalam menghadapi revolusi industri 4.0 yang datangnya bisa kapan pun. 


\section{DAFTAR PUSTAKA}

[1] Anomim. 2016. Pengertian Kepuasan Pelanggan dan Kualitas Pelayanan. http://www.landasanteori.com/2015/07/penge rtian-kepuasan-pelanggan-dan.html (diakses 18 Juli 2016)

[2] Aritonang R.L. 2005. Kepuasan Pelanggan. Gramedia. Jakarta.

[3] Cahyaningrum. 2012. Analisis Kepuasan Konsumen Atau Pelanggan Terhadap Pelayanan Jasa Pos. http://repository.uksw.edu/bitstream/1234567 89/1823/ 3/T1_162007041_BAB\%20II.pdf (diakses 10 Juli 2016)

[4] Fandy Tjiptono and Gregorius Chandra. 2007. Service, Quality Satisfaction. Andi Ofset. Yogyakarta.

[5] Irawan, H. 2003. Indonesian Customer Satisfaction. PT Gramedia Pustaka Utama. Jakarta.

[6] M. Yamin Jinca. 2011. Transportasi Laut Indonesia, Analisis Sistem dan Studi Kasus. Brilian Internasional, Surabaya.

[7] Salim Abbas. 2004. Manajemen Transportasi. Raja Gravindo Persada. Jakarta.

[8] Sugiyono. 2013. Metode Penelitian Kuantitatif Kualitatif dan R\&D. Alfabeta. Bandung.

[9] Wouter Jacobs. 2015. The Role of Port Infrastructure and Logistics in Global Networks.

http://www.iss.nl/fileadmin/ASSETS/iss/Doc uments/DevISSues/ Jacobs_WEB.pdf (diakses 15 Juli 2016) 